\title{
EARLY AND MID-HOLOCENE ENVIRONMENTAL CONDITIONS IN THE EASTERN ADRIATIC RECORDED IN SPELEOTHEMS FROM MALA ŠPILJA CAVE AND VELIKA ŠPILJA CAVE (MLJET ISLAND, CROATIA)
}

\section{REKONSTRUKCIJA OKOLIJSKIH RAZMER V ZGODNJEM IN SREDNJEM HOLOCENU NA PODLAGI ZAPISA V SIGI JAM MALA ŠPILJA IN VELIKA ŠPILJA (OTOK MLJET, HRVAŠKA)}

\author{
Nina LONČAR ${ }^{1, *}$, Miryam BAR-MATTHEWS ${ }^{2}$, Avner AYALON ${ }^{2}$, Maša SURIĆ ${ }^{1}$ \& Sanja FAIVRE ${ }^{3}$
}

\begin{abstract}
UDC 551.435.8:551.583(497.584)"628.64"

Nina Lončar, Miryam Bar-Matthews, Avner Ayalon, Maša Surić \& Sanja Faivre: Early and mid-holocene environmental conditions in the eastern Adriatic recorded in speleothems from Mala Špilja cave and Velika Špilja cave (Mljet island, Croatia)

This study presents high resolution oxygen and carbon isotopic record of two U-Th dated stalagmites from the Eastern Adriatic caves. The stalagmites were collected from Mala špilja and Velika špilja caves situated on Mljet Island in the southern part of the Croatian Adriatic. Dripwater samples were collected from Medvjeđa špilja, Strašna peć, Špilja u Vrdolje, Kraljicina spilja, Velika špilja and Mala špilja caves. All caves formed in well-stratified Cretaceous limestones. The average value of deuterium excess of the dripwater is $9.3 \%$, indicating that the atmospheric conditions over the Atlantic Ocean have greater influence on the isotopic composition precipitation in the Adriatic region than the Eastern Mediterranean Sea. The longest isotopic record of the speleothems is of stalagmite MSM-1 from Mala špilja Cave dated from 119.2 $\pm 3.3 \mathrm{ka}$ to $5.6 \pm 0.6 \mathrm{ka}$, although deposition was not continuous. During the Holocene the speleothem grew between $7 \mathrm{ka}$ and $4 \mathrm{ka}$. That interval is characterized by several $\delta^{18} \mathrm{O}_{\mathrm{c}}$ and $\delta^{13} \mathrm{C}_{\mathrm{c}}$ fluctuations reflecting changes in the environment. Superimposed on these fluctuations, there is an increasing trend in the 7.0-6.5 ka interval, evident in elevated $\delta^{18} \mathrm{O}$ values, which primarily refers the trend to drier conditions in the eastern Adriatic, which were occasionally interrupted by wet intervals. Humid conditions are particularly pronounced by low $\delta^{18} \mathrm{O}_{c}$ and $\delta^{13} \mathrm{C}_{c}$ values of speleothem MSM-1 between 7.3 and $6 \mathrm{ka}$, as a reflection of increased precipitation and lower
\end{abstract} Nina Lončar, Miryam Bar-Matthews, Avner Ayalon, Maša Surić \& Sanja Faivre: Rekonstrukcija okoljskih razmer $v$ zgodnjem in poznem Holocenu na podlagi zapisa $v$ sigi jam Mala Špilja in Velika Špilja (otok Mljet, Hrvaška)

Raziskava temelji na visoko ločljivih zapisih kisikovih in ogljikovih izotopov, pridobljenih iz dveh stalagmitov, datiranih $\mathrm{z}$ uran-torijevo metodo. Kapnika sta bila vzorčena v jamah Mala špilja in Velika špilja na otoku Mljet, v južnem delu hrvaškega Jadrana. Vzorčena je bila tudi prenikla voda v jamah Medvjeđa špilja, Strašna peć, Špilja u Vrdolje, Kraljicina spilja, Velika špilja in Mala špilja. Vse omenjene jame so v plastovitem krednem apnencu. Povprečna vrednost presežka devterija v prenikli vodi je 9,3\%o, kar kaže na prevladujoč podnebni vpliv Atlantskega oceana $\mathrm{v}$ primerjavi $\mathrm{z}$ vplivom vzhodnega Sredozemlja. Najdaljši izotopski zapis smo pridobili iz kapnika MSM-1 iz Male špilje, katerega starost je med 119,2 $\pm 3,3$ ka in $5,6 \pm 0,6 \mathrm{ka}$. Za kapnik je značilnih več prekinitev izločanja. $\mathrm{V}$ holocenu je kapnik rastel v obdobju med $7 \mathrm{ka}$ in $4 \mathrm{ka}$. V tem obdobju je več izrazitih nihanj $\delta^{18} \mathrm{O}_{c}$ in $\delta^{13} \mathrm{C}_{c}$, kar kaže na spremembe okolja. Med 7,0 in 6,5 ka je v zapisu trend naraščanja $\delta^{18} \mathrm{O}$, kar kaže na relativno suhe razmere v vzhodnem Jadranu, ki so jih občasno prekinila vlažna obdobja. Med 7,3 in 6 ka je več obdobij z nizkim vrednostmi $\delta^{18} \mathrm{O}_{\mathrm{c}}$ in $\delta^{13} \mathrm{C}^{\mathrm{c}} \mathrm{v}$ vzorcu MSM-1, kar kaže na veliko padavin in nizke temperature. Prehod v današnjo sredozemsko klimo (Cs) se je zgodil med $6 \mathrm{ka}$ in $5 \mathrm{ka}$, najbolj suha obdobja smo zabeležili med 4,7 ka in 4,2 ka. Primerjava izotopskih zapisov $\delta^{18} \mathrm{O}_{c}$ on $\delta^{13} \mathrm{C}_{\mathrm{c}}$ iz Male špilje (MSM-1) in Velike špilje (Mljet) z zapisi v jami Soreq (Izrael) in v sistemu Corchia (Italija) ter drugimi kazalci nekdanjih okolij, npr. jezerskimi sedimenti, kažejo, da sige vzhodne-
Izvleček UDK 551.435.8:551.583(497.584)"628.64"

\footnotetext{
${ }^{1}$ Department of Geography, Center for Karst and Coastal Research, University of Zadar, Trg Kneza Višeslava 9, 23000 Zadar, Croatia, e-mail:nloncar@unizd.hr,msuric@unizd.hr

${ }^{2}$ Geological Survey of Israel, Malkei Israel St 30, Jerusalem 95501, Israel, e-mail: matthews@gsi.gov.il, ayalon@gsi.gov.il

${ }^{3}$ Department of Geography, Faculty of Science, University of Zagreb, Marulićev trg 19/2, 10000 Zagreb, Croatia,

e-mail: sfaivre@geog.pmf.hr

* Corresponding author
}

Received/Prejeto: 13.02.2017 
temperatures. The transition to today's Mediterranean climate (Cs) occurred between $6 \mathrm{ka}$ and $5 \mathrm{ka}$, while the driest conditions are recorded at $\sim 4.7-4.2 \mathrm{ka}$. Comparisons between the eastern Adriatic $\delta^{18} \mathrm{O}_{c}$ and $\delta^{13} \mathrm{C}_{c}$ records of the speleothem from Mala špilja Cave (MSM-1) and Velika špilja Cave (Mljet Island) with Soreq Cave (Israel) and Corchia Cave (Italy) together with other proxies such as lake sediments demonstrate that the speleothems from the Eastern Adriatic caves record the local and the regional climatic changes.

Key words: Holocene, speleothem; stable isotopes; Eastern Adriatic, Croatia. ga Jadrana hranijo pomembne zapise o lokalnih in regionalnih podnebnih spremembah.

Ključne besede: Holocen, siga, stabilni izotopi, vzhodni Jadran, Hrvaška.

\section{INTRODUCTION}

Croatia encompasses a large part of the Eastern Adriatic region and therefore has an important role in understanding the paleoenvironmental changes in the Adriatic and the Mediterranean region. Karst occupies $43.7 \%$ of the Croatian territory (Bognar et al. 2012) and it is often referred to as Dinaric or classical karst. Studies on the paleoclimate and palaeoenvironmental changes based on speleothems from the region are mostly limited to submerged speleothems from the eastern Adriatic Sea. Based on U-Th and ${ }^{14} \mathrm{C}$ dating, and X-ray diffraction of submerged speleothems, Surić and Juračić (2010) have partially constructed curve of relative sea-level changes during the last $220 \mathrm{ka}$ for the Eastern Adriatic coast which generally corresponds to the global sea-level curve. Their studies proposed that environmental settings along eastern Adriatic varied due to climate changes, and that environmental conditions were favorable for karstification and speleothem deposition even during the Last Glacial Maximum, as in the Eastern Mediterranean region (Bar-Matthews et al. 2003) and unlike in large part of northern Europe (Gascoyne 1992; Lowe \& Walker 1998; Genty et al. 2006;

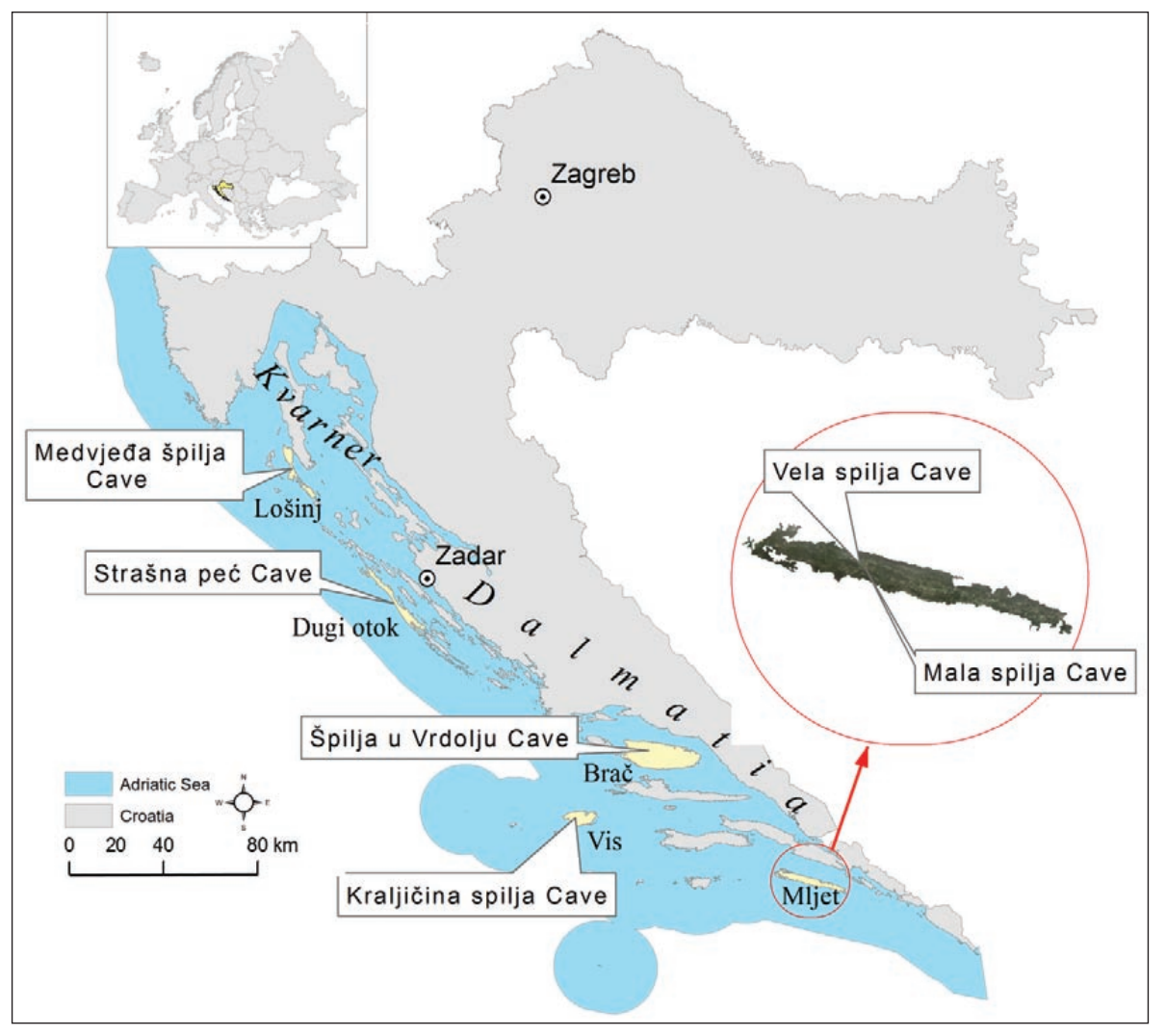

Fig. 1: Location of islands and caves included in this study. 
Moreno et al. 2010). The recent studies of Croatian speleothems (Lončar 2012) have showed that their isotopic composition records the period from the Upper Pleistocene (MIS 5) to the Upper Holocene (MIS 1), showing frequent fluctuations and abrupt changes in stable isotope values along with numerous interruptions in growth. Late Holocene stalagmites from Modrič Cave (Croatia) studied by Rudzka et al. (2012) showed alternating $\delta^{18} \mathrm{O}_{c}$ and $\delta^{13} \mathrm{C}_{c}$ variations and changes in the stalagmite diameters which were linked to periods of drier and wetter conditions.

Tufa and speleothems deposition in Croatia deposited 6000 years ago were described by Krajcar Bronić et al. (2006), Horvatinčić et al. (1989, 2000, 2003, 2008) and Surić and Juračić (2010). Precipitation and fresh water studies from several continental and coastal meteorological stations (Horvatinčić et al. 2005; Vreča et al. 2006; Surić et al. 2010; Barešić et al. 2011; Rudzka et al. 2012; Roller-Lutz et al. 2013; Hunjak et al. 2013) revealed good correlations between $\delta 1^{8} \mathrm{O}_{\mathrm{p}}$ of monthly precipitation and mean monthly air temperature, with lower seasonal variations in $\delta^{18} \mathrm{Op}$ at the maritime stations while Local Meteoric Water Lines (LMWL) are close to the Global Meteoric Water Line (GMWL) with a decreasing trend of slope for the south-Adriatic stations. Recent study of Surić et al. (2017) provided comprehensive study of precipitation and cave dripwater isotopic composition, drip rates and modern calcite stable isotope content based on two year monitoring and confirmed mutual influences of Atlantic and Mediterranean air masses on precipitation evident at study sites in the north Dalmatian islands, coast and mountain range.
Here we present speleothem $\delta^{18} \mathrm{O}_{c}$ and $\delta^{13} \mathrm{C}_{c}$ variations and $\delta^{18} \mathrm{O}_{w}$ variations of rain and dripwater collected from Mala špilja and Velika špilja caves, situated on Mljet Island and dripwater collected in four caves along the Eastern Adriatic coast (Medvjeđa špilja Cave (Lošinj Island), Strašna peć Cave (Dugi otok Island), Špilja u Vrdolje Cave (Brač Island), Kraljicina spilja Cave (Vis Island) (Fig. 1), with the aim of reconstructing of Holocene climate changes in a region. As it is already shown by numerous researches (e.g. Bar-Matthews et al. 1997, 1999, 2000; Magny et al. 2009; Bar-Matthews \& Ayalon 2011; Brayshaw et al. 2011; Giraudi et al. 2011; Peyron et al. 2011; Roberts et al. 2011; Zanchetta et al. 2011, 2014, 2016; Rudzka et al. 2012; Combourieu-Nebout et al. 2013; Finné et al. 2014) the Adriatic and Mediterranean basins are highly sensitive to climate changes and significant differences between the eastern and western basins are evident. Although stalagmites MSM-1 and VSM-1 have longer depositional period, the purpose of this paper is to give preliminary results for the Holocene environmental settings. Namely, Holocene environmental change records for Croatia are scarce but unlike the older depositional periods, can be reliably compared with other research results.

The interpretation of MSM-1 and VSM-1 records are made in terms of local, regional and larger scale climate dynamics, in order to provide new insights to local and regional Holocene climate settings and links between the eastern and western Mediterranean sub-basins.

\section{GEOGRAPHICAL, GEOLOGICAL AND CLIMATE SETTINGS}

The Adriatic, as well as the rest of the Mediterrenean is influenced by air masses of different origin, causing noticeable spatial and seasonal variability of the meteorological parameters over the basin (Vreča et al. 2006; Lionello et al. 2006). Croatia is situated in the northern part of the temperate zone (Fig. 1) where air masses from the northwest Atlantic Ocean and dry and hot air from North Africa (Šegota \& Filipčić 2003) meet mainly in the southeast. According to the Köppen-Geiger climate classification (Peel et al. 2007), the northern part of the Adriatic is classified as humid subtropical climate (Cfa), with wetter summers and colder and drier winters while the southern Adriatic is classified as hot summer Mediterranean climate (Csa). The air temperature can fluctuate by about $20^{\circ} \mathrm{C}$ during a season (Artegiani et al. 1997). The eastern part of the basin is much wetter than the western part and maximum precipitation occurs along the southeastern coast (Cushman-Roisin et al. 2001). High air pressure zone prevails over the Croatian Adriatic in the summer months, while the rest of the year is marked by frequent changes of cyclones and anticyclones which move eastward. Climate settings during the summer months are determined mainly by the Azores High which brings stable weather, particularly in the southern part of the Adriatic (Penzar et al. 2001) region. Winter months are determined by the Icelandic and Siberian High. The predominant winter winds are bora gusty downslope windstorm characteristic for the eastern Adriatic coast (Grisogono \& Belušić 2009) which brings cold and dry continental air and sirocco that brings humid and warm 
Tab. 1: Summary of cave characteristics and sampling location.

\begin{tabular}{|c|c|c|c|c|c|c|c|c|}
\hline Cave & $\begin{array}{l}\text { Position } \\
\text { (WGS 84) }\end{array}$ & $\begin{array}{l}\text { Alt. } \\
(m .)\end{array}$ & $\begin{array}{l}\text { Lenght/ } \\
\text { depth }(m)\end{array}$ & $\begin{array}{l}\text { Vegetation } \\
\text { and average } \\
\text { overburden } \\
\text { (m) }\end{array}$ & $\begin{array}{l}\text { Cave air } \\
\text { temp. }\left({ }^{\circ} \mathrm{C}\right)\end{array}$ & $\begin{array}{l}\text { Cave air } \\
\text { relative } \\
\text { humidity (\%) }\end{array}$ & $\begin{array}{l}\text { Sample } \\
\text { location } \\
\text { ( } m \text { from the } \\
\text { entrance) }\end{array}$ & Sample* \\
\hline $\begin{array}{l}\text { Medvjeđa } \\
\text { špilja (Lošinj } \\
\text { Island) }\end{array}$ & $\begin{array}{l}44^{\circ} 36^{\prime} 22.4^{\prime \prime} \mathrm{N} \\
14^{\circ} 24^{\prime} 44.6^{\prime \prime} \mathrm{E}\end{array}$ & 17.5 & $245 /-25$ & $\begin{array}{l}\text { scarce Medit. } \\
\text { maquis } \\
19 \pm 5\end{array}$ & 15 & 100 & 20 & WMS-1 \\
\hline $\begin{array}{l}\text { Strašna peć } \\
\text { (Dugi otok } \\
\text { Island) }\end{array}$ & $\begin{array}{l}44^{\circ} 0^{\prime} 16^{\prime \prime} \mathrm{N} \\
15^{\circ} 2^{\prime} 19^{\prime \prime} \mathrm{E}\end{array}$ & 72 & $110 /-14$ & $\begin{array}{l}\text { scarce Medit. } \\
\text { maquis } \\
27 \pm 5\end{array}$ & 11.5 & 100 & $\begin{array}{l}60 \\
65\end{array}$ & $\begin{array}{l}\text { WSPD-1 } \\
\text { WSPD-2 }\end{array}$ \\
\hline $\begin{array}{l}\text { Špilja u } \\
\text { Vrdolje (Brač } \\
\text { Island) }\end{array}$ & $\begin{array}{l}43^{\circ} 21^{\prime} 10^{\prime \prime} \mathrm{N} \\
16^{\circ} 36^{\prime} 22^{\prime \prime} \mathrm{E}\end{array}$ & 310 & $87 / 0$ & $\begin{array}{l}\text { dense Medit. } \\
\text { maquis } \\
30 \pm 5\end{array}$ & 13.5 & - & 75 & WSUV-1 \\
\hline $\begin{array}{l}\text { Kraljicina } \\
\text { spilja } \\
\text { (Vis Island) }\end{array}$ & $\begin{array}{l}44^{\circ} 04^{\prime} 18.9^{\prime \prime} \mathrm{N} \\
16^{\circ} 06^{\prime} 02.6^{\prime \prime} \mathrm{E}\end{array}$ & 70 & $60 / 0$ & $\begin{array}{l}\text { scarce Medit. } \\
\text { maquis } \\
30 \pm 5\end{array}$ & 14.1 & - & 55 & WVKS-1 \\
\hline $\begin{array}{l}\text { Mala Špilja } \\
\text { (Mljet Island) }\end{array}$ & $\begin{array}{l}42^{\circ} 45^{\prime} 51.6^{\prime \prime} \mathrm{N} \\
17^{\circ} 28^{\prime} 33.5^{\prime \prime} \mathrm{E}\end{array}$ & 60 & $25 /-9$ & $\begin{array}{l}\text { scarce Medit. } \\
\text { maquis } \\
12 \pm 5\end{array}$ & 13 & 96.3 & $\begin{array}{l}40 \\
40\end{array}$ & $\begin{array}{l}\text { WMSa } \\
\text { MSM-1 }\end{array}$ \\
\hline $\begin{array}{l}\text { Velika špilja } \\
\text { (Mljet Island) }\end{array}$ & $\begin{array}{l}42^{\circ} 45^{\prime} 53^{\prime \prime} \mathrm{N} \\
17^{\circ} 28^{\prime} 19^{\prime \prime} \mathrm{E}\end{array}$ & 90 & $40 / 0$ & $\begin{array}{l}\text { scarce Medit. } \\
\text { maquis } \\
8 \pm 1\end{array}$ & 14 & 95 & $\begin{array}{l}13 \\
13 \\
13\end{array}$ & $\begin{array}{c}\text { WNVSa-1 } \\
\text { WNVSb } \\
\text { VSM-1 }\end{array}$ \\
\hline
\end{tabular}

${ }^{*}$ regular letters for water sample, bold for stalagmite samples

air and occasionally Saharan sand causing the rain dust (Cushman-Roisin et al. 2001).

Croatian Eastern Adriatic coast encompasses north and middle Adriatic region and it can be divided into the northern part i.e. Kvarner region, and Dalmatia region which is in the middle and southern part. The coast, including the islands, is composed mainly of carbonate rocks deposited in a shallow marine environment, with occasional emerging (Jelaska 2002). Pliocene and Pleistocene sea level fluctuations caused primarily by cyclic growth and decay of ice sheets (Lambeck \& Chappell 2001) lead to the emersions of carbonate areas which together with tectonics and favourable climatic conditions enabled the karstification of today's eastern Adriatic coast (Surić et al. 2014). Pleistocene-Holocene transgression raised sea level by about $135 \mathrm{~m}$ (Church et al. 2004) and flooded today's North Adriatic area submerging the lower zones forming numerous islands. The present geomorphological features of the eastern Adriatic coast are a reflection of fault tectonics, in the general NW-SE direction (Prelogović et al. 1995). Therefore, the littoral is characterised by the parallelism of the coastline, island chains and major geological and geomorphological structures known as Dalmatian type (Fairbridge 1968). Relief of all islands is characterized by typical macro and micro karst forms which are predetermined by the geologic structure and the alteration of limestone and dolostones (Bognar \& Curić 1995).
Lošinj Island is located in the southernmost part of Kvarner region between $44^{\circ} 42 \mathrm{~N}, 14^{\circ} 24^{\prime} \mathrm{E}$ and $44^{\circ}$ $28^{\prime} \mathrm{N}, 14^{\circ} 32^{\prime} \mathrm{E}$, stretching for $31 \mathrm{~km}$ in a NW-SE direction with surface area of $74.37 \mathrm{~km}^{2}$ (Duplančić Leder et al. 2004). The Lošinj Island (Fig. 1) makes the transition area between Mediterranean climate with hot summers (Csa) and moderately warm and humid climate in winter (Cfa) (Filipčić 2000). According to the Croatian Meteorological and Hydrological Service (CMHS 2010), the average annual air temperature for the years 19812008 on Lošinj Island is $15.3^{\circ} \mathrm{C}$. Medvjeđa špilja Cave is situated in the central part of the island $\sim 55 \mathrm{~m}$ from the sea (Fig. 1, Tab. 1). The entrance to the cave is through a narrow shaft formed along NNE-SSW direction cracks (Malez \& Božićević 1965). It is 245 meters long cave which from the entrance descends for $25 \mathrm{~m}$ forming a bell shaped chamber and continues in channel mostly submerged by the sea (Jalžić, 2007). The cave is rich in mostly submerged speleothems with few dry parts in the entrance covered with clastic material (so-called Beach) and several walls and rocks covered with speleothem.

Dugi otok Island is located in the middle part of the Croatian Adriatic (north Dalmatia) (Fig. 1; Tab.1), situated between $44^{\circ} 09^{\prime} \mathrm{N}, 14^{\circ} 49^{\prime} \mathrm{E}$ and $43^{\circ} 52^{\prime} \mathrm{N}, 15^{\circ} 12^{\prime}$ E, extending $44.4 \mathrm{~km}$ with surface area of $113.31 \mathrm{~km}^{2}$. The climate is Mediterranean with hot summers and wet winters (Csa). Mean annual air temperature (MAAT) is $16.4{ }^{\circ} \mathrm{C}$ (CHMS 2010). Strašna peć Cave is situated in the middle of the Island (Fig. 1; Tab. 1) on the west sea- 
ward side (Fig. 1). The cave formed in Upper Cretaceous limestone. Average limestone thickness above the cave is $27 \pm 5 \mathrm{~m}$. The cave is divided into two chambers $25 \times 20 \mathrm{~m}$ and $30 \times 15 \mathrm{~m}$ size ending with steep, $14 \mathrm{~m}$ deep shaft filled with collapsed material. It is rich with speleothems, many of which are large inactive stalagmites and pillars at the entrance, corroded due to their exposure to the atmosphere. Active speleothems prevail around the edges of the shaft.

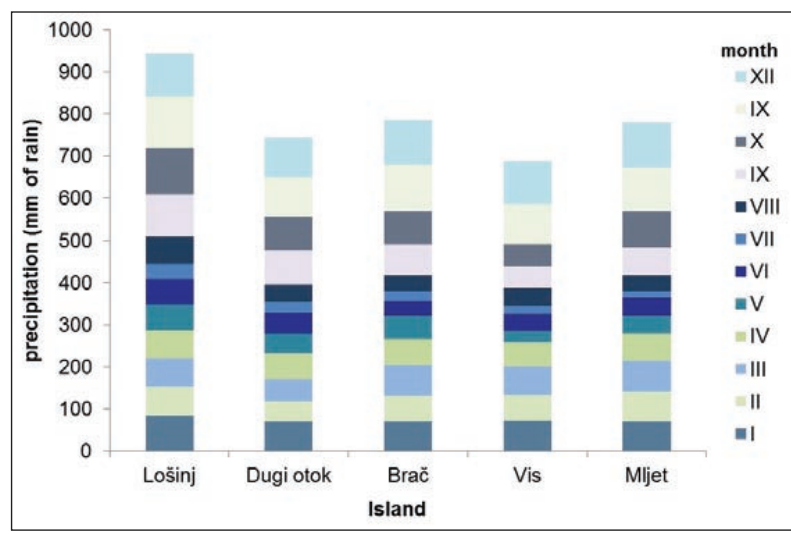

Fig. 2: Comparison of yearly and monthly average amount of rainfall (1981-2008) on studied islands (CMHS, for the 19812008 period).

Brač Island with total area of $395.44 \mathrm{~km}^{2}$ (Duplančić Leder et al. 2004) is the largest Dalmatian island, situated between $43^{\circ} 23^{\prime} \mathrm{N}$ and $16^{\circ} 25^{\prime} \mathrm{E}$ and $43^{\circ} 17^{\prime} \mathrm{N}, 16^{\circ} 53^{\prime} \mathrm{E}$. From the mainland it is separated by the channel 6-13 $\mathrm{km}$ Brač Channel. Climatically it belongs to Csa region with MAAT $16.4{ }^{\circ} \mathrm{C}$ (CHMS 2010) with typical Mediterranean vegetation. Špilja u Vrdolje Cave is located in Vrdolje area in the NW part of the Island (Fig. 1; Tab. 1). The entrance to the cave is small ( $\sim 0.90$ m wide), located along the road and overgrown with thick scrub. This is a channel cave formed in Cretaceous limestones. The channel stretches horizontally $\sim 2 \mathrm{~m}$ in width, but in some parts it narrows up to $0.5 \mathrm{~m}$. In most parts the cave floor is covered with clay and mud, while at the end of channel there are many stalagmite and pillars.
Vis Island is also a part of middle Dalmatia dominated by Csa climate. It is $17 \mathrm{~km}$ long and $8 \mathrm{~km}$ wide with an area of $89.72 \mathrm{~km}^{2}$ it is Situated between $43^{\circ} 03^{\prime} \mathrm{N}$, $16^{\circ} 02^{\prime} \mathrm{E}$ and $43^{\circ} 01^{\prime} \mathrm{N}, 16^{\circ} 13^{\prime} \mathrm{E}$ is the most maritime island with the highest MAAT of $17^{\circ} \mathrm{C}$. Kraljicina spilja Cave is situated on the northern coast of the island (Fig. 1; Tab. 1) and so far is the largest known cave on the Vis Island. Morphological it is branched cave consists of five chambers and several smaller channels separated by massive stalagmites, pillars and curtains (facets) (Kaiser \& Forenbacher 2002).

Mljet Island is the eighth largest $\left(98.02 \mathrm{~km}^{2}\right)$ island in Croatia with an average width of only $3 \mathrm{~km}$. It is elongated in shape, and stretches in NW-SE direction for $37 \mathrm{~km}$. The island is located between $42^{\circ} 48^{\prime} \mathrm{N}, 17^{\circ} 19^{\prime} \mathrm{E}$ and $42^{\circ} 41^{\prime} \mathrm{N}, 17^{\circ} 45^{\prime} \mathrm{E}$ and is the southernmost and easternmost island among the large Croatian islands. The MAAT is $16.6^{\circ} \mathrm{C}$. Mala špilja Cave is located on a steep northern slope in the middle of the Island (Fig. 1; Tab. 1). The cave is formed in well-stratified Cretaceous limestone. The entrance is small $(0.5 \times 0.5 \mathrm{~m})$ and vertical ( $9 \mathrm{~m}$ deep), followed by a $40 \mathrm{~m}$ long channel, which forms the main chamber (Jalžić et al. 2007). The cave is rich in speleothems, especially stalactites, stalagmites and columns. Velika špilja Cave is located in the vicinity of the Mala špilja Cave (Fig. 1; Tab. 1). The entrance to the cave is horizontal, probably due to a collapse, as evident by the many collapsed blocks in the front and inside the cave. From the entrance, the cave is descending and opens to an $8 \mathrm{~m}$ high chamber. The cave is rich in speleothems and the entire left wall of the main chamber is covered by a thick flowstone layer.

Among these islands, the highest annual rainfall is in northern Adriatic (Kvarner region) on the Lošinj Island $(942 \mathrm{~mm})$. The wettest months on the island are September, October and November, while the driest month is July (Fig. 3). On the southern islands (Dugi otok, Brač, Vis and Mljet) the rainiest month are November and December and the driest is July. For instance, in July Mljet receives only $16.1 \mathrm{~mm}$ (CMHS 2010).

\section{MATERIALS AND METHODS}

Dripwater samples were collected during 2010 in Medvjeđa špilja, Strašna peć, Špilja u Vrdolje, Kraljicina spilja, Velika špilja and Mala špilja cave. The location and timing of collecting the, cave dripwater, temperature, relative humidity and other parameters are given in Tab. 1 and 2. Cave dripwater samples have been collected using $300 \mathrm{ml}$ bottles with a plastic funnel near the location from which the stalagmite samples were taken. The relative humidity and cave temperature were measured on site with HOBO U23 Pro v2 Temperature/ 
Relative Humidity Data Logger during the dripwater collection.

Stable hydrogen and oxygen isotope compositions of water samples were measured at the geochemical lab of the Geological Survey of Israel (GSI), and they are expressed as $\delta \mathrm{D}$ and $\delta^{18} \mathrm{O}$ values (in \%o) relative to $\mathrm{V}$ SMOW (Tab. 2). Hydrogen isotope composition was measured by ThermoFinnigan HighTemperature Conversion Elemental Analyzer (TC/EA) attached to a Delta $\mathrm{V}$ ThermoFinnigan mass spectrometer. The measurements were carried out at a reaction temperature of $1450{ }^{\circ} \mathrm{C}$ (Nelson 2000). Oxygen isotope composition was measured by ThermoFinnigan GasBenchII attached to a Delta Plus mass spectrometer. The $\delta^{18} \mathrm{O}$ measurements were carried out using the $\mathrm{CO}_{2}$-water equilibration technique (Epstein \& Mayda 1953). The precision of these measurements was $\pm 0.1 \%$ for $\delta^{18} \mathrm{O}$ and $\pm 1.5 \%$ for $\delta \mathrm{D}$.

Stalagmite samples were collected in all caves but here we present the results only from caves on Mljet Island. Sample MSM-1 is a $34 \mathrm{~cm}$ long stalagmite (Fig. 3) collected at the end of the Mala špilja Cave (Tab. 1). The speleothem is the top of $\sim 30 \mathrm{~cm}$ of an almost $1 \mathrm{~m}$ long, calcite stalagmite. Before sampling, the speleothem was actively growing from fast dripping water. After cutting the sample into two halves along the growth axis, it was found that the sample is composed of two well-laminated stalagmites (MSM-1-L and MSM-1-R, Fig. 3). The laminae appear in variable colours: white to light and dark reddish-brown. Sample VSM-1 (Fig. 3) from Velika špilja Cave is a $24 \mathrm{~cm}$ long stalagmite, $\sim 6.0 \mathrm{~cm}$ in diameter, collected at the upper part of a big flowstone, close to the roof $(\sim 2 \mathrm{~m})$. It is composed of two parts. The bottom part is compact white and light brown calcite and the top part is brown, porous, grainy, sandy and corroded.

The speleothems were dated using the U-Th method. The procedures for extraction and purification of $U$ and Th as well as methodology of U-Th dating followed the procedure described in details by Vaks et al. (2006), Gopher et al. (2010), and Bar-Matthews and Ayalon (2011). Sub-samples of 0.1-1.0 g of speleothem material were drilled using $0.5-4.0 \mathrm{~mm}$ diameter diamond drill bits. All samples were completely dissolved in a combination of $7 \mathrm{M} \mathrm{HNO}_{3}$ and $\mathrm{HF}$, and spiked with a mixed
${ }^{229} \mathrm{Th} /{ }^{236} \mathrm{U}$ spike. The reproducibility of ${ }^{234} \mathrm{U} /{ }^{238} \mathrm{U}$ ratio was $0.1 \%(2 \sigma)$. The samples were loaded into mini columns containing 2 ml Bio-Rad AG 1X8 200-400 mesh resin. $\mathrm{U}$ was eluted by $1 \mathrm{M} \mathrm{HBr}$ and Th with $6 \mathrm{M} \mathrm{HCl}$. $\mathrm{U}$ and Th solutions was evaporated to dryness and the residue dissolved in $2 \mathrm{ml}$ and $5 \mathrm{ml}$ of $0.1 \mathrm{M} \mathrm{HNO}_{3}$, respectively. U-Th dating was performed at the GSI geochemical laboratory using a $\mathrm{Nu}$ Instruments Ltd (UK) MC-ICP-MS equipped with 12 Faraday cups and 3 ion counters. Each sample was introduced to the MC-ICPMS through an Aridus ${ }^{\circledR}$ micro-concentric desolvating nebuliser sample introducing system. The instrumental mass bias was corrected (using the exponential equation) by measuring the ${ }^{235} \mathrm{U} /{ }^{238} \mathrm{U}$ ratio and correcting with the natural ${ }^{235} \mathrm{U} /{ }^{238} \mathrm{U}$ ratio. Calibration of ion-counters relative to Faraday cups was performed using several cycles of measurements with different collector configurations in each particular analysis. The U-Th method assumes that all ${ }^{230} \mathrm{Th}$ present in the calcite speleothem is formed in situ by radioactive decay of uranium that co-precipitated with the calcite. However, this component is often present in detrital material such as clays, oxides and hydroxides (Kaufman et al. 1998; Richards \& Dorale 2003). For this correction, $\mathrm{a}^{232} \mathrm{Th} /{ }^{238} \mathrm{U}$ atomic ratio of 3.8 (the average crustal value, Taylor \& McLennan 1985) in the detrital components was used.

For $\delta^{18} \mathrm{O}_{c}$ and $\delta^{13} \mathrm{C}_{\mathrm{c}}$ analyses, speleothem samples of $1-2 \mathrm{mg}$ material were drilled every $\sim 0.5-1.0 \mathrm{~mm}$ using a $0.8-1.0 \mathrm{~mm}$ diameter drill along the growth axis averaging of $\sim 0.8 \mathrm{~mm} /$ sample. $\delta^{18} \mathrm{O}_{c}$ and $\delta^{13} \mathrm{C}_{\mathrm{c}}$ measurements were performed was performed at the geochemical laboratory of GSI using a Gas Bench system attached to a Delta Plus ThermoFinnigan mass spectrometer. All $\delta^{18} \mathrm{O}_{c}$ and $\delta^{13} \mathrm{C}$ values were calibrated against the international standard NBS-19 and in-house standard Carrara Marble, and are reported in per mille (\%o), relative to the V-PDB standard. Analytical reproducibility of duplicates is better than $0.1 \%$ both for $\delta^{18} \mathrm{O}_{c}$ and $\delta^{13} \mathrm{C}_{c}$.

A continuous isotopic record was obtained by assuming that the measured age represents the center of the drilled area, and that there is a constant growth-rate between two adjacent dated points.

\section{RESULTS}

\section{ISOTOPE RATIOS OF HYDROGEN AND OXYGEN} OF CAVE DRIPWATER

$\delta^{18} \mathrm{O}_{\text {w }}$ of cave water vary from $-6.32 \%$ to $-7.03 \%$ and $\delta \mathrm{D}$ vary from $-47.9 \%$ to $-39.6 \%$ (Tab. 2 ). The calculat- ed value of $\mathrm{d}$-excess (d-excess is defined as $\delta \mathrm{D}-8^{*} \delta^{18} \mathrm{O}$ ) in each sample varies from $4.4 \%$ to $12.2 \%$, closely following the Meteoric Water Line of $9.3 \%$, apart for sample WMSa with d-excess of $4.4 \%$. 
Tab. 2: Dripwater isotope values.

\begin{tabular}{l|l|l|c|c|c}
\hline Sample & Cave & Collecting period & $\begin{array}{c}\delta^{18} \text { O } \\
\% \text { (VSMOW) }\end{array}$ & $\begin{array}{c}\delta D \\
\% \text { (VSMOW) }\end{array}$ & $\begin{array}{c}d \text {-excess } \\
(\% o)\end{array}$ \\
\hline WMSa & Mala špilja & 20-22 Feb 2010 & -6.54 & -47.9 & 4.4 \\
WNVSb & Velika špilja & 20-22 Feb 2010 & -6.76 & -44.2 & 9.9 \\
WNVSa-1 & Velika špilja & 20-22 Feb 2010 & -6.77 & -41.9 & 12.2 \\
WSUV-1 & Špilja u Vrdolju & $18-19$ May 2010 & -7.03 & -47.5 & 8.7 \\
WSPD-2 & Strašna peć & 20 Jun-29 Sep 2010 & -6.82 & -44.9 & 9.7 \\
WVKS-1 & Kraljicina spilja & 19-20 May 2010 & -6.32 & -39.6 & 11 \\
WMS-1 & Medvjeđa špilja & 13 Dec 2009-10 Jan 2010 & -6.65 & -43.9 & 9.3 \\
\hline
\end{tabular}

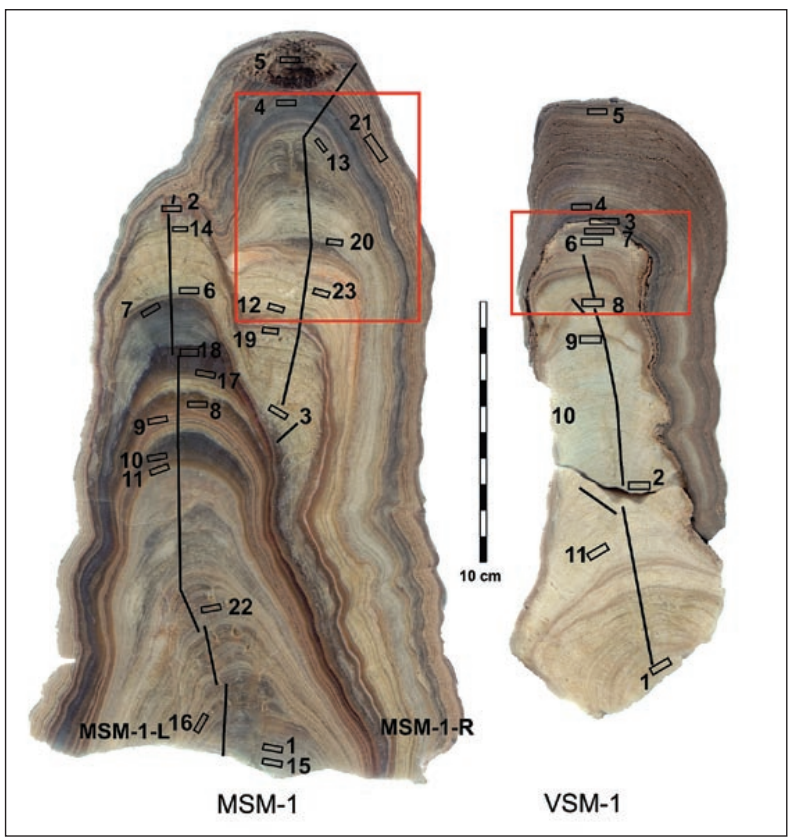

Fig. 3: Longitudinal section of the stalagmite MSM-1 and VSM-1. Black squares mark U-Th dating samples positions (real depth); solid lines indicate growth axes along which the samples for the stable isotopes were taken, red squares mark the subsamples discussed in this paper.

\section{AGE OF THE SPELEOTHEM SAMPLES}

Twenty-three U-Th ages were determined on stalagmite MSM-1, and seven on stalagmite VSM-1. Isotope ratios are given in Tab. 3 as activity ratios with 2 sigma uncertainties. The reproducibility of ${ }^{234} \mathrm{U} /{ }^{238} \mathrm{U}$ ratio was $0.11 \%$ $(2 \sigma)$. The degree of initial contamination of ${ }^{230} \mathrm{Th}$ from detritus was estimated by measuring the ${ }^{230} \mathrm{Th} /{ }^{232} \mathrm{Th}$ activity.

Only 13 sub-samples, all extracted from the sample MSM-1, satisfy this criterion, and their age has the smallest correction. All other sub-samples had low ${ }^{230} \mathrm{Th} /{ }^{232} \mathrm{Th}$ activity and corrections were much higher. Most dating (23 samples) were performed on the larg-

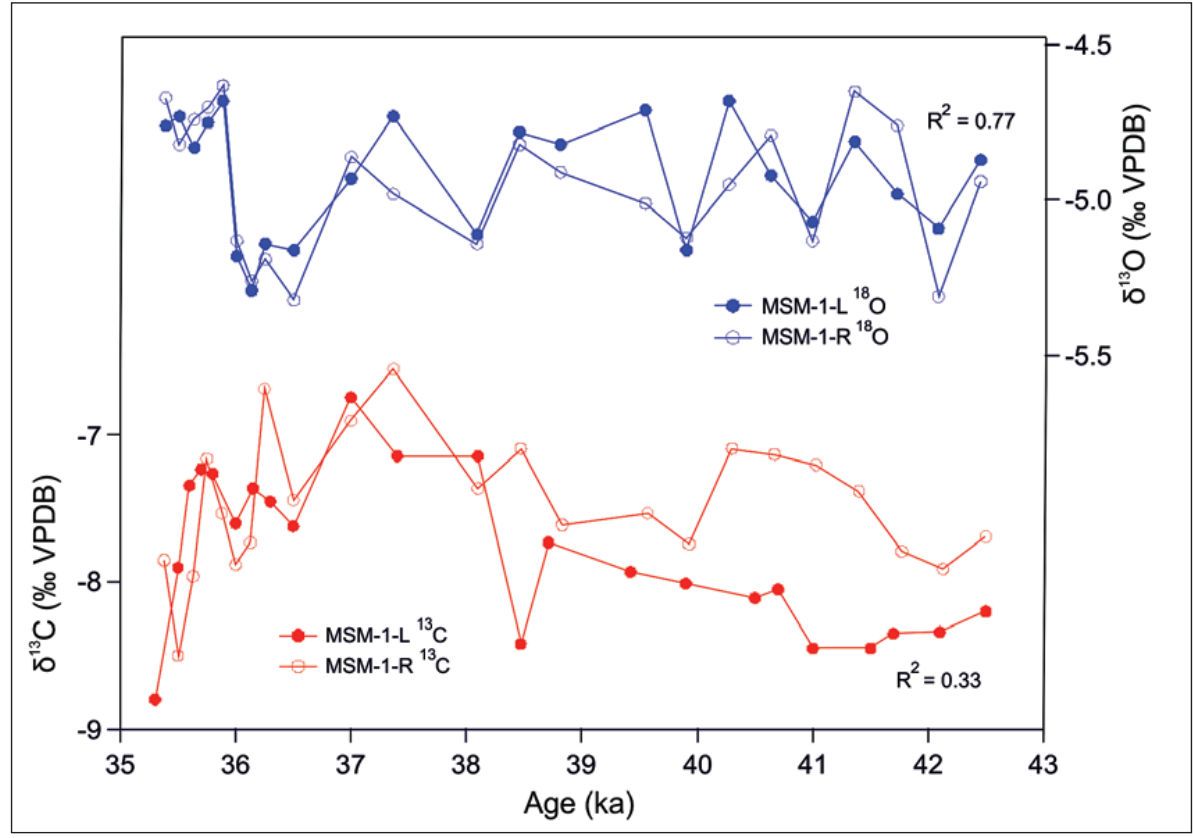

Fig. 4: Replication Test for stalagmites MSM-1-L and MSM-1-R. 
NINA LONČAR, MIRYAM BAR-MATTHEWS, AVNER AYALON, MAŠA SURIĆ \& SANJA FAIVRE

Tab. 3: Detailed dating results for the Holocene portion of the calcitic stalagmites MSM-1 and VSM-1.

\begin{tabular}{|c|c|c|c|c|c|c|c|c|c|c|c|}
\hline \multirow[t]{2}{*}{ sample } & \multirow[t]{2}{*}{${ }^{238} U_{p p m}$} & \multirow[t]{2}{*}{ $\pm 2 \sigma$} & \multirow[t]{2}{*}{$\left({ }^{234} U{ }^{238} U\right)_{A}$} & \multirow[t]{2}{*}{ $\pm 2 \sigma$} & \multirow[t]{2}{*}{$\left({ }^{230} T h /{ }^{32} T h\right)_{A}$} & \multirow[t]{2}{*}{ $\pm 2 \sigma$} & \multirow[t]{2}{*}{$\left({ }^{230} T h /^{234} U\right)_{A}$} & \multirow[t]{2}{*}{ $\pm 2 \sigma$} & \multicolumn{2}{|c|}{ Age (ka) } & \multirow[t]{2}{*}{$\begin{array}{l}\text { Depth } \\
\text { from top } \\
(\mathrm{mm})\end{array}$} \\
\hline & & & & & & & & & & Corr. & \\
\hline VSM-1-5 & 0.1829 & 0.0001 & 1.03974 & 0.0017 & 2.8 & 0.08 & 0.3522 & 0.0092 & $47.1 \pm 3.1$ & 35.0 & 7 \\
\hline VSM-1-3 & 0.2381 & 0.0001 & 1.03187 & 0.0012 & 3.0 & 0.02 & 0.2570 & 0.0013 & $32.3 \pm 0.4$ & 24.3 & 50 \\
\hline VSM-1-7 & 0.1767 & 0.0002 & 1.02685 & 0.0022 & 4.9 & 0.14 & 0.0980 & 0.0027 & $11.2 \pm 1.0$ & 9.3 & 53 \\
\hline VSM-1-8 & 0.2070 & 0.0002 & 1.02539 & 0.0014 & 2.7 & 0.06 & 0.1193 & 0.0025 & $13.8 \pm 1.0$ & 9.7 & 82 \\
\hline VSM-1-9 & 0.2020 & 0.0003 & 1.02509 & 0.0023 & 11.3 & 0.27 & 0.1245 & 0.0030 & $14.5 \pm 1.0$ & 13.4 & 97 \\
\hline VSM-1-10 & 0.1860 & 0.0002 & 1.02653 & 0.0013 & 7.8 & 0.17 & 0.1533 & 0.0034 & $18.1 \pm 0.9$ & 16.2 & 126 \\
\hline VSM-1-2 & 0.2402 & 0.0002 & 1.02988 & 0.0019 & 6.0 & 0.16 & 0.1943 & 0.0051 & $23.5 \pm 1.4$ & 20.5 & 146 \\
\hline VSM-1-11 & 0.2110 & 0.0001 & 1.02848 & 0.0019 & 8.9 & 0.22 & 0.1582 & 0.0039 & $18.7 \pm 1.0$ & 17.1 & 178 \\
\hline VSM-1-1 & 0.2261 & 0.0074 & 1.04301 & 0.0011 & 7.1 & 0.14 & 0.2613 & 0.0052 & $32.9 \pm 1.6$ & 29.4 & 219 \\
\hline MSM-1-2 & 0.1645 & 0.0000 & 1.01570 & 0.0017 & 1.8 & 0.01 & 0.5768 & 0.0026 & $93.2 \pm 1.5$ & 60.4 & 7 \\
\hline MSM-1-14 & 0.1382 & 0.0001 & 1.04981 & 0.0024 & 23.6 & 0.34 & 0.3115 & 0.0045 & $40.5 \pm 1.5$ & 39.2 & 12 \\
\hline MSM-1-21 & 0.1910 & 0.0002 & 1.01515 & 0.0022 & 3.5 & 0.09 & 0.0657 & 0.0017 & $7.4 \pm 0.6$ & 5.6 & 16 \\
\hline MSM-1-5 & 0.3111 & 0.0002 & 1.01120 & 0.0014 & 1.8 & 0.02 & 0.2301 & 0.0027 & $28.4 \pm 1.0$ & 16.2 & 22 \\
\hline MSM-1-4 & 0.2255 & 0.0001 & 1.00920 & 0.0010 & 2.4 & 0.02 & 0.1373 & 0.0009 & $16.1 \pm 0.5$ & 10.5 & 27 \\
\hline MSM-1-6 & 0.1703 & 0.0001 & 1.06082 & 0.0016 & 39.4 & 0.25 & 0.2950 & 0.0018 & $37.9 \pm 0.6$ & 37.2 & 37 \\
\hline MSM-1-3 & 0.1602 & 0.0001 & 1.06250 & 0.0021 & 16.4 & 0.11 & 0.3424 & 0.0024 & $45.4 \pm 1.0$ & 43.5 & 37 \\
\hline MSM-1-13 & 0.2979 & 0.0002 & 1.02800 & 0.0017 & 14.4 & 0.32 & 0.0601 & 0.0013 & $6.7 \pm 0.8$ & 6.3 & 43 \\
\hline MSM-1-18 & 0.1383 & 0.0002 & 1.04379 & 0.0023 & 97.3 & 2.74 & 0.4410 & 0.0120 & $63.0 \pm 5.0$ & 62.5 & 57 \\
\hline MSM-1-17 & 0.2908 & 0.0003 & 1.05999 & 0.0027 & 77.1 & 0.84 & 0.5500 & 0.0058 & $86.0 \pm 3.0$ & 85.3 & 69 \\
\hline MSM-1-20 & 0.1230 & 0.0001 & 1.01657 & 0.0036 & 8.9 & 0.34 & 0.0920 & 0.0036 & $10.5 \pm 1.0$ & 9.5 & 75 \\
\hline MSM-1-8 & 0.3892 & 0.0003 & 1.06298 & 0.0008 & 56.4 & 0.38 & 0.5793 & 0.0035 & $93.1 \pm 2.0$ & 92.2 & 80 \\
\hline MSM-1-9 & 0.5477 & 0.0004 & 1.04579 & 0.0016 & 16.9 & 0.09 & 0.6277 & 0.0032 & $106.4 \pm 2.5$ & 103.0 & 85 \\
\hline MSM-1-23 & 0.2020 & 0.0002 & 1.02179 & 0.0027 & 11.8 & 0.29 & 0.1003 & 0.0024 & $11.5 \pm 0.7$ & 10.7 & 99 \\
\hline MSM-1-10 & 0.3513 & 0.0052 & 1.03832 & 0.0027 & 46.4 & 0.17 & 0.6427 & 0.0026 & $110.9 \pm 1.8$ & 109.6 & 102 \\
\hline MSM-1-12 & 0.2292 & 0.0015 & 0.98519 & 0.0129 & 11.7 & 0.42 & 0.0683 & 0.0026 & $7.7 \pm 0.1$ & 7.1 & 105 \\
\hline MSM-1-11 & 0.1966 & 0.0002 & 1.04446 & 0.0027 & 66.9 & 0.89 & 0.6806 & 0.0086 & $122.6 \pm 6.0$ & 121.7 & 107 \\
\hline MSM-1-19 & 0.1453 & 0.0002 & 1.05189 & 0.0026 & 37.9 & 0.96 & 0.2934 & 0.0073 & $37.6 \pm 2.3$ & 36.9 & 117 \\
\hline MSM-1-7 & 0.1991 & 0.0001 & 1.04913 & 0.0014 & 116.8 & 0.67 & 0.3991 & 0.0022 & $55.1 \pm 0.8$ & 54.8 & 143 \\
\hline MSM-1-22 & 0.2491 & 0.0004 & 1.05760 & 0.0020 & 47.8 & 0.33 & 0.6619 & 0.0044 & $116.2 \pm 3.0$ & 115.0 & 162 \\
\hline MSM-1-16 & 0.2479 & 0.0002 & 1.04491 & 0.0017 & 53.2 & 0.42 & 0.6591 & 0.0051 & $115.7 \pm 3$ & 114.6 & 198 \\
\hline MSM-1-1 & 0.2317 & 0.0001 & 1.03750 & 0.0007 & 72.3 & 0.32 & 0.6226 & 0.0026 & $105.1 \pm 1.5$ & 104.3 & 213 \\
\hline MSM-1-15 & 0.2490 & 0.0002 & 1.04353 & 0.0016 & 137.3 & 1.12 & 0.6716 & 0.0050 & $119.7 \pm 3.3$ & 119.2 & 222 \\
\hline
\end{tabular}

est sample MSM-1 due to its complex structure and numerous hiatus (Fig. 3). It resulted in longer record dated from $119.2 \pm 3.3 \mathrm{ka}$ to $5.6 \pm 0.6 \mathrm{ka}$, but deposition was not continuous.

Speleothem MSM-1 is composed of two well-laminated stalagmites (MSM-1-L and MSM-1-R) (Fig 3). The older white part grew between $\sim 119$ and $37 \mathrm{ka}$. Only the top of $\sim 5 \mathrm{~cm}$ of MSM-1-R grew during the Holocene between $\sim 7 \mathrm{ka}$ and $\sim 4 \mathrm{ka}$.
Stalagmite VSM-1 (Fig. 3) is composed of two parts. The inner white portion grew between $\sim 17$ and $\sim 13 \mathrm{ka}$, while the upper $\sim 5 \mathrm{~cm}$ grew between $\sim 10$ to $\sim 9 \mathrm{ka}$ (Tab. 3). The outer (younger) brown part was difficult to date since it contains large amount of detrital components.

Age model was performed assuming constant growth rate between two dated intervals suggesting that the Holocene portion covered by the two speleothems 


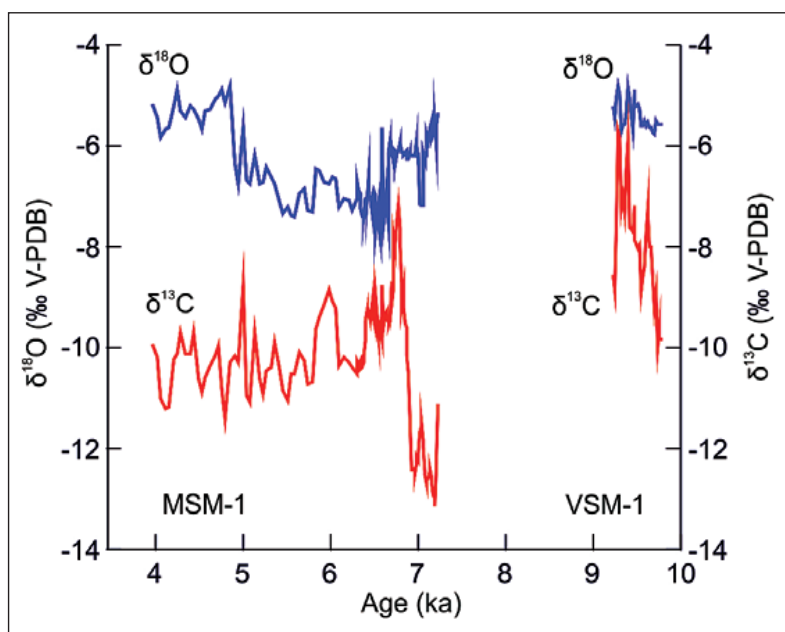

Fig. 5: Holocene $\delta 18 O c$ and $\delta^{13} C_{c}$ profile of stalagmite VSM-1 and $M S M-1$

covers the time intervals between $\sim 10$ to $9 \mathrm{ka}$ (VSM-1), and between 7.5 to $4 \mathrm{ka}(\mathrm{MSM}-1)$.

\section{$\delta^{18} \mathrm{O}$ AND $\delta^{13} \mathrm{C}$ PROFILES}

In order to verify that the speleothems were deposited in isotopic equilibrium a replication test (Bar-Matthews et al. 1997; Dorale \& Liu 2009), comparing the $\delta^{18} \mathrm{O}_{c}$ and $\delta^{13} \mathrm{C}_{\mathrm{c}}$ values of the two portions of MSM speleothem, MSM-1-L with MSM-1-R, for the same time interval was performed. The test showed strong relationship $\left(\mathrm{R}^{2}=0.77\right)$ between $\delta^{18} \mathrm{O}_{c}$ MSM-1-L and $\delta^{18} \mathrm{O}_{c}$ MSM-1-L, and some relationship (R2=0.33) between $\delta^{13} \mathrm{C}_{c} \quad \mathrm{MSM}-1-\mathrm{L}$ and $\delta^{13} \mathrm{C}_{\mathrm{c}}$ MSM-1-L (Fig. 4).

$\delta^{18} \mathrm{O}$ and $\delta^{13} \mathrm{C}$ analyses were performed on stalagmites MSM-1 and VSM-1, for the time period from 9.8 to $4 \mathrm{ka}$. The age model of VSM-1 suggests that during the Holocene the stalagmite was deposited from $9.8 \mathrm{ka}$ to $9.2 \mathrm{ka}$. The $\delta^{18} \mathrm{O}$ values fluctuate in amplitude of $1.0 \%$ between $\sim-6.0 \%$ and $\sim-5.0 \%$, and $\delta^{13} \mathrm{C}_{\mathrm{c}}$ values vary between $-10 \%$ and $-6.0 \%$ (Fig. 5). Minimum $\delta^{18} \mathrm{O}_{c}$ value is $-5.78 \%$ at $9.7 \mathrm{ka}$ and maximum peak of $\delta^{18} \mathrm{O}$ c value of $-4.8 \%$ is at $9.3 \mathrm{ka}$, coupled with a maximum $\delta^{13} \mathrm{C}_{\mathrm{c}}$ peak of $-5.7 \%$ at the same time. Given the short deposition period of VSM-1, these fluctuations can be considered significant, especially the increasing trend in both $\delta^{18} \mathrm{O}_{c}$ and mainly $\delta^{13} \mathrm{C}_{\mathrm{c}}$ between $9.8 \mathrm{ka}$ and $9.4 \mathrm{ka}$.

The $\delta^{18} \mathrm{O}_{c}$ and $\delta^{13} \mathrm{C}_{c}$ records during the younger time interval from $7.5 \mathrm{ka}$ to $4 \mathrm{ka}$ (MSM-1) are characterized by several modes: a very sharp increase over $\sim 500$ years in $\delta^{13} \mathrm{C}_{\mathrm{c}}$ from $\sim-12 \%$ to $\sim-7 \%$ from 7.5 to 7 ka negatively correlated with the sharp decrease in $\delta^{18} \mathrm{O}_{\mathrm{c}}$ values from $\sim-6 \%$ to $\sim-8 \%$. From $\sim 6.8 \mathrm{ka}$ to $5.5 \mathrm{ka} \delta^{18} \mathrm{O}_{c}$ show minimum values of $\sim-7.5 \%$ to $-6.5 \%$ and a sharp increase from $5.5 \mathrm{ka}$ to $5.0 \mathrm{ka}$ from $\sim-7.5 \%$ to $\sim-5.0 \%$ whereas $\delta^{13} \mathrm{C}_{\mathrm{c}}$ values are almost constant vary only between $-7.0 \%$ and $-6.5 \%$. Between 5 and $4 \mathrm{ka}, \delta^{18} \mathrm{O}_{c}$ values frequently fluctuate in amplitude of $\sim 1 \%$, with maximum value of $-4.9 \%$ around $4.7-4.2 \mathrm{ka}$ (Fig. 5).

\section{DISCUSSION}

\section{CAVE DRIPWATER}

All dripwater samples follow closely the GMWL with dexcess of $\sim 10 \%$ and Western Mediterranean Meteoric Water Line (WMMWL) (Fig. 6) indicating that the main source of precipitation are the Atlantic air masses. That is in concordance with previous and recent regional studies which have shown that Croatia receives both Atlantic and Mediterranean moisture (Surić et al. 2017).

Comparison between the dripwater isotopic composition and rain water from several stations in Croatia stations: Malinska (as a reference station for the northern Adriatic Sea), Zadar (as a reference station for the central Adriatic) and Dubrovnik and Komiža (as a reference stations for the southern Adriatic), and a station in Zagreb representing continental climate (Horvatinčić et al. 2005; Krajcar Bronić et al. 2006; Vreča et al. 2006), shows that the $\delta^{18} \mathrm{O}-\delta \mathrm{D}$ relationships of all the cave water follow closely the GMWL although local lines with lower d-excess characterize the southern Adriatic stations with lower slopes $(<7)$ and intercepts $(<5)$ due to higher temperatures and possible evaporation of raindrops below the clouds (Krajcar Bronić et al. 2006). The present-day cave water $\delta^{18} \mathrm{O}-\delta \mathrm{D}$ relations suggest that the main source for cave water is rainfall associated with the Atlantic Ocean water vapour. But, since the dripwaters were collected in several caves along the eastern Adriatic coast line only once and at different seasons, such data are difficult to compare and they can not provide insight to the possible seasonal isotopic variation in the dripwater. For example, Strašna peć Cave dripwater sampled in this study (SPD-2) has $\delta^{18} \mathrm{O}$ value of $-6.82 \%$, which is in very good agreement with mean $\delta^{18} \mathrm{O}$ value of $-6.7 \%$ obtained from two year (2013-2015) cave monitoring in Strašna peć (Surić et al. 2017). Since the first monitoring was performed during the short summer/autumn period $\delta$ D is $5 \%$ lower than mean 2013-2015 value. 


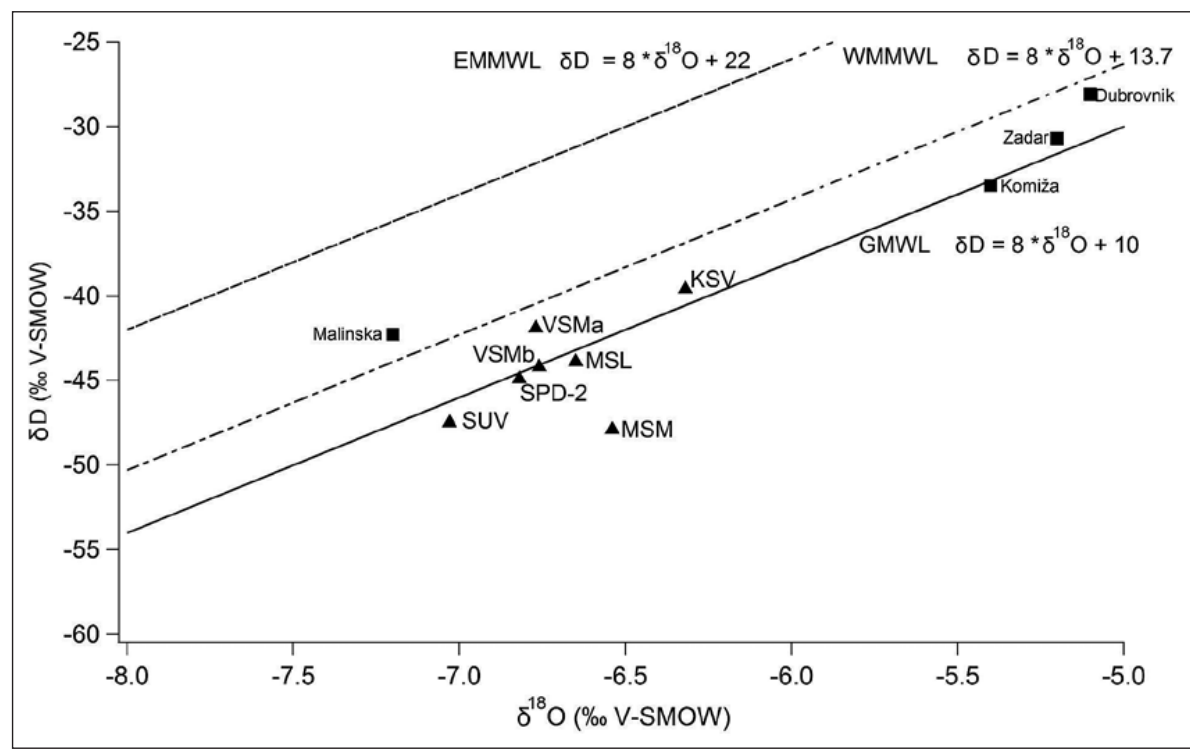

Fig. 6: $\delta D$ vs. $\delta^{18} \mathrm{O}$ values of drip cave water from the Medvjeda špilja (MSL) Strašna peć Cave (SPD-2), Špilja u Vrdolju Cave, (SUV), Kraljicina spilja Cave (KSV), Velika špilja Cave (VSM) and Mala špilja Cave (MSM) (triangles) and mean annual $\delta D$ vs. $\delta^{18} \mathrm{O}$ values of Dubrovnik, Komiža, Malinska and Zadar GNIP stations (squares) in relation to the Global Meteoric Water Line (GMWL) (Dansgaard 1964), Eastern Mediterranean Water Line (MMWL) (Gat \& Carmi 1987) and Western Mediterranean Meteoric Water Line (WMMWL)(Celle-Jeanton et al. 2001).

The overall values of cave dripwater from the Medvjeđa špilja (MSL) Strašna peć Cave (SPD-2), Špilja u Vrdolju Cave, (SUV), Kraljicina spilja Cave (KSV), Velika špilja Cave (VSM) and Mala špilja Cave (MSM) are close to each other and to the analytical precision. On the other hand, the lower isotopic composition of the cave water compared with local rainfall values suggests that the cave waters are mainly derived from the massive rain events, characterised by lower $\delta^{18} \mathrm{O}$ and $\delta \mathrm{D}$ values, and/or because winter precipitation has higher chance to reach the cave, since summer evapotranspiration reduces the effective infiltration.

\section{$\delta^{18} \mathrm{O}$ AND $\delta^{13} \mathrm{C}$ TIME SERIES}

Stable isotope analyses conducted on speleothem VSM-1 and MSM-1 revealed frequent fluctuations and abrupt changes in $\delta^{18} \mathrm{O}\left(\delta^{18} \mathrm{O}_{c}\right)$ and $\delta^{13} \mathrm{C}\left(\delta^{13} \mathrm{C}_{c}\right)$ values expressed in a number of peak values. Important changes of the stable isotopic composition and positive correlation between $\delta^{18} \mathrm{O}_{c}$ and $\delta^{13} \mathrm{C}_{c}$ are evident in different stages of speleothem growth.

Replication test for stalagmites MSM-1-L and MSM-1-R shows good correspondence of isotopic signal. Strong correlation $\left(\mathrm{R}^{2}=0.77\right)$ between $\delta^{18} \mathrm{O}_{c}$ (Fig. 4) supports the equilibrium conditions during the deposition of stalagmite. Namely, according to Dorale and Liu (2009) such simultaneous variations can be an indication of changes in both, climate and vegetation productivity. Moreover, stalagmites with diameters of more than $11 \mathrm{~cm}$ are considered to reflect isotopic characteristic of drip water, and therefore are reliable for environmental reconstructions (Dreybodt \& Scholz 2011; Belli et al., 2013). Assuming that the speleothems were deposited in isotopic equilibrium as demonstrated by the Replication test, the calcite $\delta^{18} \mathrm{O}_{c}$ variations reflect variations in the cave water $\delta^{18} \mathrm{O}$ and cave temperatures. It was found that the isotopic signal derived from the analysed speleothems is affected by many factors. Amount effect has a major impact on the $\delta^{18} \mathrm{O}_{c}$ and therefore its value primarily reflects the amount of moisture in the certain period. Decrease of $\delta^{18} \mathrm{O}_{c}$ indicates wet, and the increase of $\delta^{18} \mathrm{O}$ indicates dry conditions.

It can be expected that the $\delta^{13} \mathrm{C}_{\mathrm{c}}$ values of MSM-1 and VSM-1 primarily reflect biogenic production of soil $\mathrm{CO}_{2}$ associated with the climatic factors since according to van Adel and Tzedakis (1996) there was no significant predominance of $\mathrm{C} 4$ vegetation in the eastern Adriatic region during the Holocene. Namely, data obtained from the cave speleothems from the northern Europe show that $80-90 \%$ of the speleothem carbon is of biogenic origin $\left(\mathrm{CO}_{2}\right.$ from the soil) while speleothem $\delta^{13} \mathrm{C}_{\mathrm{c}}$ value is connected with the vegetation cover density and microbial activity of cave overburden (Genty \& Massault 1997, 1999; Vogel \& Kronfeld 1997; Weiner 2011). Since the soil moisture and temperature are driving factors in soil microbial respiration (Fairchild \& Baker, 2012) $\delta^{13} \mathrm{C}_{c}$ values of MSM-1 and VSM-1 can be considered as proxy that reflects the athmosperic conditions above the caves. In such cases lamina thickness variations can be related to $\delta^{13} \mathrm{C}_{c}$ anomalies (Belli et al., 2013) and can be considered for our samples. We presume that $\delta^{13} \mathrm{C}_{c}$ of analysed speleothems primarily reflects the density and/or type of vegetation cover and biogenic activity in the soil. Negative $\delta^{13} \mathrm{C}_{c}$ values usually indicate abundance of vegetation and more humid climate conditions, while more positive $\delta^{13} \mathrm{C}_{c}$ values point to drought conditions and reduced biogenic activity.

Considering abovementioned, low $\delta^{18} \mathrm{O}_{c}$ and $\delta^{13} \mathrm{C} c$ of speleothems MSM-1 and VSM-1 are mostly indicators of humid climate, while high $\delta^{18} \mathrm{O}_{c}$ and $\delta^{13} \mathrm{C}_{c}$ values 


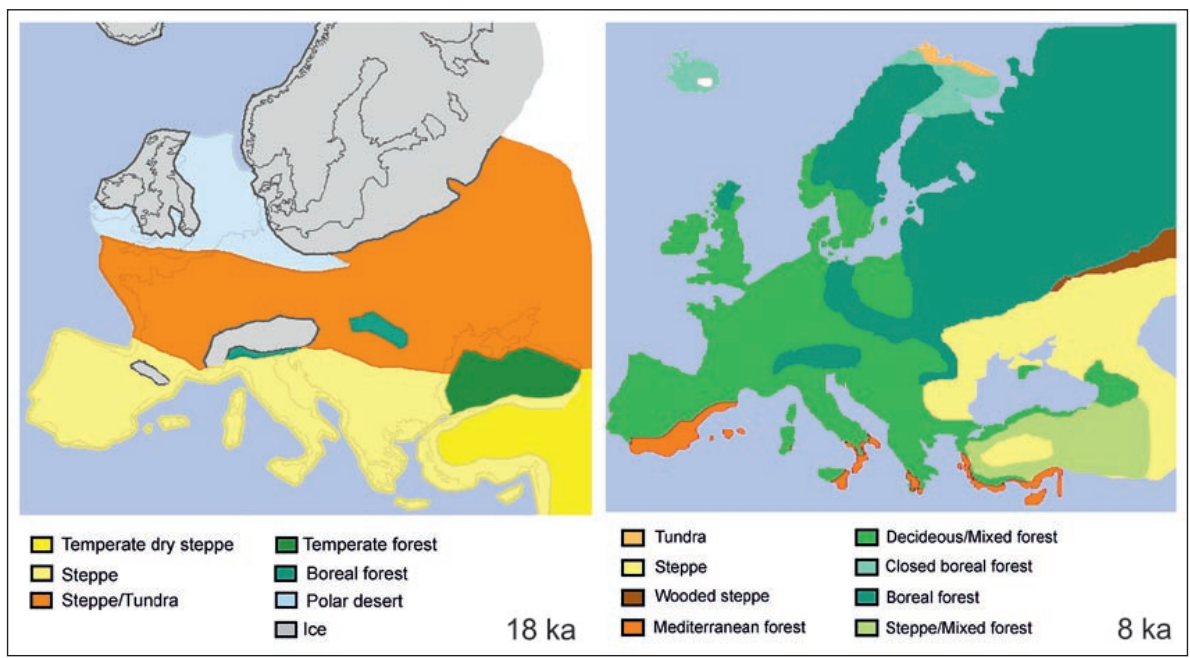

Fig. 7: Vegetation cover 18000 and 8000 years ago (after Tzedakis 2005; Adams \& Faure 1997; Adams et al. 1999 and Adams n.d., modified).

indicate relatively dry conditions. In the case of negative correlation between $\delta^{18} \mathrm{O}_{c}$ and $\delta^{13} \mathrm{C}_{c}$, lower $\delta^{18} \mathrm{O}_{c}$ values may be the result of hot and humid conditions, while the dry climate may lead to higher $\delta^{13} \mathrm{C}_{\mathrm{c}}$ values $(\mathrm{McDermott}$ et al. 1999). In the Mediterranean region, speleothem $\delta^{18} \mathrm{O}_{\mathrm{c}}$ is mainly controlled by precipitation where more negative values indicate wet periods (Bard et al. 2002; Bar-Matthews et al. 1999, 2000). However both $\delta^{18} \mathrm{O}_{c}$ and $\delta^{13} \mathrm{C}_{c}$ can be interpreted differently, depending on factors that at some point had a decisive influence on the isotopic signal.

\section{EARLY HOLOCENE}

Early Holocene most commonly refers to pre-boreal and boreal period (11.7-8 ka) (McDermott et al. 1999), but sometimes chronologically encompasses $10-7$ ka period (Bar-Matthews \& Ayalon 2011). Isotopic profile of stalagmite VSM-1 from Velika špilja cave covers the period between $9.8 \mathrm{ka}$ and $9.3 \mathrm{ka}$ (Fig. 3 and 5). Low $\delta^{13} \mathrm{C}_{\mathrm{c}}$ values at $9.8 \mathrm{ka}$ and an increasing trend toward $9.3 \mathrm{ka}$ suggest an environmental change from relatively humid conditions to less humid conditions, a change that was most likely associated with a change in the vegetation type. The vegetation cover along the Eastern Adriatic in the early Holocene was characterized by mixed deciduous forests (Adams et al. 1999) (Fig. 7).

Low $\delta^{13} \mathrm{C}$ values at $9.8 \mathrm{ka}$, reflecting humid conditions at that time, can be related to increased rainfall in the coastal areas of the Mediterranean, which was typical for the early Holocene, and associated, with changes in the character of cyclonic depression (Roberts et al. 2011). Warm and humid conditions in the Adriatic region were determined also by pollen analysis from boreholes (Zonneveld 1996).

Almost continuous increase of $\delta^{13} \mathrm{C}_{c}$ values of stalagmite VSM-1 with the high peak of $\delta^{18} \mathrm{O}_{c}$ and $\delta^{13} \mathrm{C}_{c}$ values at $9.4 \mathrm{ka}$ (Fig. 5) indicates transition to dryer conditions which probably lead to the changes in vegetation soil biogenic activity, since between $\sim 9 \mathrm{ka}$ and $\sim 7$ ka mixed deciduous oak forest with only a few representatives of Mediterranean vegetation prevailed on Mljet Island (Jahns \& van den Bogaard 1998). Thus, the increase in $\delta^{13} \mathrm{C}_{c}$ values cannot be due to change in vegetation but more likely they reflect reduced moisture due to warming. Warming conditions are also evident from Vransko jezero Lake on Cres Island (North Dalmatia), which recorded increase proportion of evergreen oak (Quercus ilex) (Schmidt et al. 2000). This assumption is in concordance with the newest findings form Vransko jezero lake sediments indicating transition from colder to warmer Holocene climate from 9.6-9.3 ka (Bakrač et al. 2015). Warming and dry conditions between $9 \mathrm{ka}$ and $7.8 \mathrm{ka}$ were recorded in the isotopic signal in speleothems from the Italian cave Grotta di Ernesto (McDermott et al. 1999). Average surface temperature of the Mediterranean Sea was up to $2.9^{\circ} \mathrm{C}$ higher than today (Marchal et al. 2002) thus it is possible that the dry conditions recorded by the $\delta^{18} \mathrm{O}_{c}$ and $\delta^{13} \mathrm{C}_{c}$ values of stalagmite VSM-1 reflect warming in the entire Eastern Adriatic region. Extremely dry conditions between $9.5 \mathrm{ka}$ and $9 \mathrm{ka}$ were also recorded in the western Mediterranean (SE France - SE Spain) (Jalut et al. 2000) and it is very likely that such conditions prevailed in the wider area of Mljet Island.

\section{MIDDLE HOLOCENE}

Middle Holocene refers in the present study to the time period between 7 and $4 \mathrm{ka}$. The paleoenvironmental changes along the eastern Adriatic coast can be reconstructed from the isotopic record of stalagmite MSM-1 from Mala špilja Cave (Figs. 3 and 5). During the mid-Holocene, $\delta^{13} \mathrm{C}_{c}$ values are more constant and change within $\pm 2 \%$ indicating that during this period the vegetation cover remained rather constant as was proposed by Wunsam 


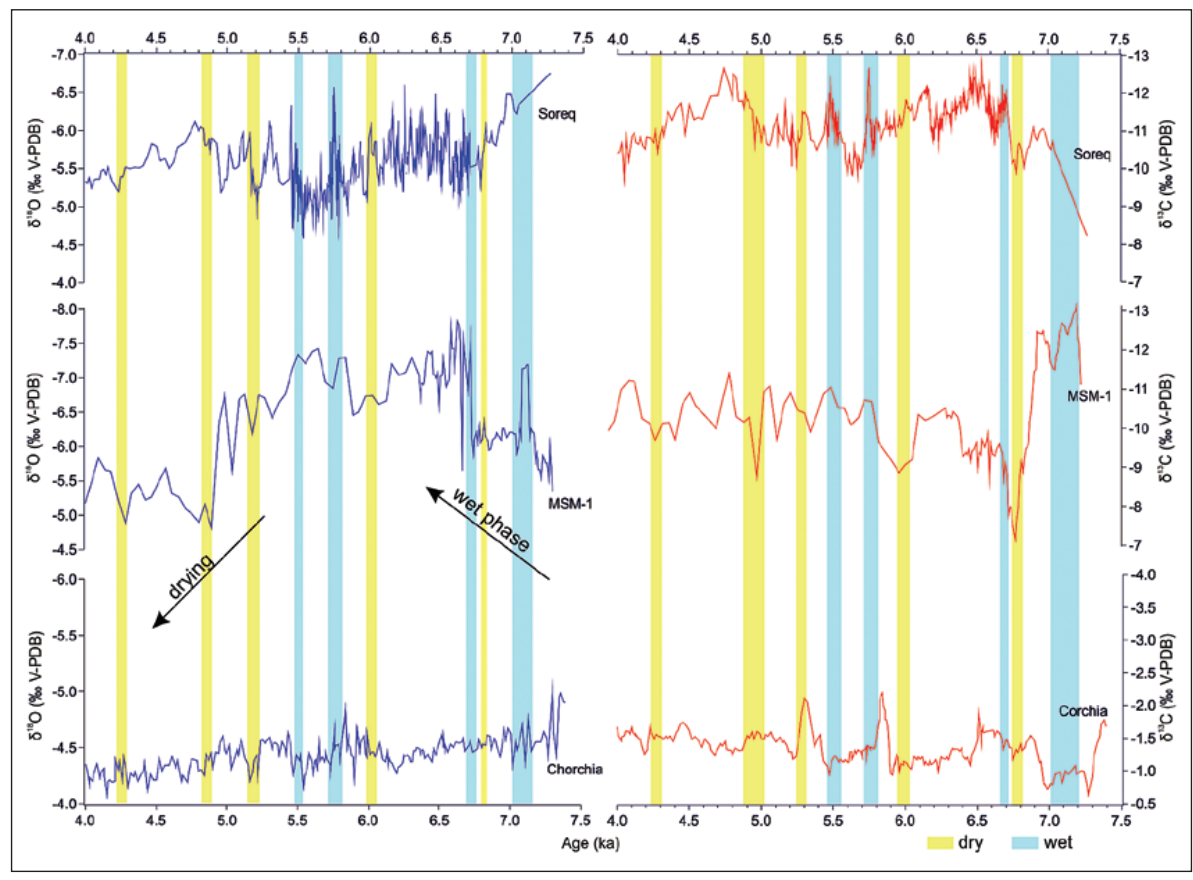

Fig. 8: The $\delta^{18} \mathrm{O}_{c}$ and $\delta^{13} \mathrm{C}_{c}$ records of MSM-1, compared with the isotopic records of Corchia (Drysdale et al. 2005) and Soreq caves (Bar-Matthews et al. 2003). The age offset between the records (in the order of up to several hundreds of years) has to be considered in the context of age uncertainties.

et al. (1999) and Tzedakis et al. (2005). Consequently, the most important environmental changes are interpreted based on $\delta^{18} \mathrm{O}$ oscillations. We suggest that changes in the $\delta^{18} \mathrm{O}_{c}$ of MSM-1 during the mid-Holocene reflect mainly changes in the rainfall amount (Bar-Matthews et al. 1996, 2000; Drysdale et al. 2004; Belli et al., 2013).

Based on the large isotopic fluctuations several short-term climatic events can be observed: The wettest phase evident from lowest $\delta^{18} \mathrm{O}_{c}$ and $\delta^{13} \mathrm{C}_{c}$ values coupled with highest growth rate is between $7.2^{c} \mathrm{ka}$ and $6.4 \mathrm{ka}$. There is a negative correlation between $\delta^{18} \mathrm{O}$ and $\delta^{13} \mathrm{C}_{\mathrm{c}}$ before $7.2 \mathrm{ka}$, i.e. the lowest $\left(-13.1 \%\right.$ o $\delta^{13} \mathrm{C}_{\mathrm{c}}$ and high $(-5.5 \% 0) \delta^{18} \mathrm{O}_{c}$ (Fig. 5) accompanied by increased MSM-1 speleothem growth rate. The very low $\delta^{13} \mathrm{C}_{\mathrm{c}}$ values are indicative for very wet periods as was also suggested for other temperate regions including Croatia (Fairchild et al. 2006).

The increase of $\delta^{13} \mathrm{C}_{\mathrm{c}}$ after $7 \mathrm{ka}$ with maximum $\delta^{13} \mathrm{C}$ value of $-7.2 \%$ at $\sim 6.8 \mathrm{ka}$ and rather low $\delta^{18} \mathrm{O}_{c}(-6.1 \%$ ) (Figs. 5 and 8) points to relative dryer climate which lasted 200 years, and ends with extremely wet event at $6.6 \mathrm{ka}$ in the area of Mljet Island and its surroundings. Between $6.5 \mathrm{ka}$ and $5.5 \mathrm{ka}$ there is slight increase in $\delta^{13} \mathrm{C}$ (by $\sim 2 \%$ ) and decrease of growth rate which are probably connected to the transition to the Mediterranean climate whereas $\delta^{18} \mathrm{O}_{c}$ values at that time are still very low ranging between $-7.7 \%$ and $-6.6 \%$ coupled with relatively low $\delta^{13} \mathrm{C}$, and could be linked to a wet period associated with cooling and decrease in winter temperatures (Mayewski et al. 1997 in Zanchetta et al. 2014). There are two dry events at $6 \mathrm{ka}$ and $5.6 \mathrm{ka}$, evident from sharp decrease of $\delta^{13} \mathrm{C}_{c}$ and growth rate, each followed by wet events at 5.8 and $5.5 \mathrm{ka}$ as evident by the low $\delta^{18} \mathrm{O}_{\mathrm{c}}$ $\left(-7.2 \%\right.$ ) coupled with low $\delta^{13} \mathrm{C}_{\mathrm{c}}(\sim-11 \%$ ). This phase is followed by short ( 400 years) return to lower values and increased growth rate with two events of reduced rainfall/moisture centered at $5.4 \mathrm{ka}$ and $5.2 \mathrm{ka}$ and two events of increased rainfall amount at $5.3 \mathrm{ka}$ and $5.1 \mathrm{ka}$. Transition towards drier late Holocene is evident from progressive increase of $\delta^{18} \mathrm{O}_{c}$ coupled with relatively high $\delta^{13} \mathrm{C}_{\mathrm{c}}$ which points to reduction in rainfall. It starts at $5 \mathrm{ka}$ with sharp increase in $\delta^{13} \mathrm{C}_{c}(-8.8 \%$ ) and lowest growth rate which continues onwards. High $\delta^{18} \mathrm{O}_{c}$ and $\delta^{13} \mathrm{C}_{c}$ and at $\sim 4.8 \mathrm{ka}$ points to reduced moisture, while the driest phase is recorded in high $\delta^{18} \mathrm{O}_{c}$ coupled with relatively constant $\delta^{13} \mathrm{C}_{c}(\sim-10 \%)$ between $4.5 \mathrm{ka}$ and $4.2 \mathrm{ka}$.

Given the high concordance between the MSM-1 isotopic profile, changes in vegetation cover recorded in sediments from Malo jezero Lake and the Veliko jezero Lake on Mljet Island on the one side, and global warming followed by the maximum transgression on the other, we can conclude that the stable isotope profile of stalagmite MSM-1 reliably reflects mid-Holocene climate as fluctuations between relatively wet and relatively dry conditions.

\section{THE REGIONAL CONTEXT OF MSM-1 ISOTOPE RECORD}

Climatic conditions recorded in stalagmite MSM-1, can be linked to changes in the Mediterranean environment recorded in speleothems from wider region (Fig. 8). Since the Adriatic region is bordering area between Atlantic and Mediterranean atmospheric and ocean circulation influence (Davis et al. 2003; Roberts et al. 2011), 
it is suggested that wet conditions have prevailed during deposition of Sapropel (S1), affected also the central part of Eastern Adriatic where Mljet Islands is located. Wet conditions during deposition of $\mathrm{S} 1$ have been recorded in the western Mediterranean (Corchia Cave, Italy) (Zanchetta et al. 2007, 2014). It is most likely that the southern parts of Croatian Adriatic were influenced by the Mediterranean atmospheric conditions. We suggest that wetter conditions associated with the period of sapropel S1 depositions as recorded between $7 \mathrm{ka}$ and $6.8 \mathrm{ka}$ in Soreq cave (Bar-Matthews et al. 2000, 2003) (Fig. 8) and in lake sediments from Vransko jezero Lake (Croatia) (Bakrač et al. 2015) also influenced this part of the Adriatic region. Wet conditions during the period of S1 sapropel deposition is recorded also in alpine caves speleothems (Spötl et al. 2010).

The relative dry event at $6.8 \mathrm{ka}$ can be related to transition from wet early Holocene to drier mid Holocene, but also marks the end of S1 influence and may be correlated to the $6.8 \mathrm{ka}$ North Atlantic ice-rafting event (Bond et al. 2001) which is also recorded in North Africa (Rashid et al. 2013) and in Swiss Alps as a short-lived glacier re-advance (Luetscher et al. 2011). At $\sim 6.6 \mathrm{ka}$, a wet event is observed, marked by significant low $\delta^{18} \mathrm{O}_{c}$ value of $-7.8 \%$ (Figs. 8 and 9), while $\delta^{13} \mathrm{C}_{c}$ profile is quite constant. Frisia et al. (2006) suggested that high $\delta^{13} \mathrm{C}$ variability from $7.5 \mathrm{ka}$ to $6.5 \mathrm{ka}$ is transitional period from a pluvial early Holocene to the present-day climate conditions interrupted by periods of relatively dry winters. It is possible that the short lasting isotopic dry and wet events at $6.8 \mathrm{ka}$ and $6.6 \mathrm{ka}$ respectively, represent seasonality changes and may indicate changes between dryer and wetter winters or storm tracks.

Sharp decrease of $\delta^{18} \mathrm{O}_{c}$ and $\delta^{13} \mathrm{C}_{c}$ values (Fig. 5) and high growth rate $(100 \mathrm{~mm} / \mathrm{ka})$ of MSM-1, recorded between 7.3 and $6.5 \mathrm{ka}$ suggests wet period in the eastern Adriatic coast mainly in the wider area of Mljet Island. Wunsam et al. (1999) recorded wet conditions on Mljet Island in Malo jezero and Veliko jezero lake sediments which began before $8.4 \mathrm{ka}$ followed by an increased amount of rainfall with maximum between 7 and $6 \mathrm{ka}$. Bakrač et al. (2015) recorded wet period in Vransko jezero (near Biograd) lake sediment, where the change in the vegetation cover in north Dalmatia is connected with increased river inputs around the Adriatic basin from the central Adriatic borderlands around 7.5-7.0 ka (Combourieu-Nebout et al. 2013). Both records are in very good agreement with wet periods recorded in MSM-1 $\delta^{18} \mathrm{O}_{c}$ and $\delta^{13} \mathrm{C}_{c}$ values. Mid-Holocene wet conditions were also reported in most parts of central and southern Europe (Harrison et al. 1993). The average surface temperature of the Mediterranean Sea was reduced by about $2.5^{\circ} \mathrm{C}$, and there was a decrease in salinity of Tyrrhenian
Sea (Kallel et al. 1997 in Wunsam et al. 1999). Isotope records of stalagmites from Clamouse Cave (southern France) and Ernesto Cave (NW Italy) (McDermott et al. 1999) confirmed an increased amount of precipitation as also evident in Soreq Cave (Bar-Matthews \& Ayalon 2011).

When comparing MSM record with Soreq and Corchia there is very good correlation in isotopic profiles, especially in increase of values from mid to late Holocene which is most evident from 5 ka onwards. In MSM- 1 humid period, there is similarity in between Corchia and MSM record around $7 \mathrm{ka}$. In particular there is good match in intervals with higher values at $\sim 6 \mathrm{ka}, 5.6 \mathrm{ka}$, $5.2 \mathrm{ka}, 5 \mathrm{ka}$ and $\sim 4.2 \mathrm{ka}$, and lower values at $\sim 5.8 \mathrm{ka}$ and $\sim 5.5 \mathrm{ka}$ (Fig. 8) suggesting that at that time all sites were under influence of the same atmospheric circulation. They were probably affected by the North Atlantic circulation and changes in SST where higher temperatures increased summer aridity and winter precipitation (Sanchez Goni et al. 1999; Drysdale et al. 2009). Wet phase before $5.8 \mathrm{ka}$ evident from in all profiles is recorded also in Sofular Cave (Turkey) (Göktürk et al. 2011). On the other hand, there is negative correlation between MSM and Soreq $\delta^{13} \mathrm{C}_{\mathrm{c}}$ isotopic profiles between $6.5 \mathrm{ka}$ and $6 \mathrm{ka}$ suggesting that these caves were under different atmospheric influence.

In the regional context, Wunsam et al. (1999) suggest that the transition to modern Mediterranean climate (Cs) occurred between $6.3 \mathrm{ka}$ and $5.5 \mathrm{ka}$, when conditions in the paleoenvironment became drier with most of the rainfall during the winter followed by gradual decrease during summer. Between $\sim 5 \mathrm{ka}$ and $\sim 4$ ka there is noticeable increase in $\delta^{13} \mathrm{C}$ and $\delta^{18} \mathrm{O}$ values and lower growth rate and gradual narrowing of stalagmite MSM-1. Highest $\delta^{18} \mathrm{O}_{c}$ peak $(-4.9 \%$ ) at $4.8 \mathrm{ka}$ and $4.3 \mathrm{ka}$, and an increase in $\delta^{13} \mathrm{C}$ to $-8.8 \%$ at $\sim 5.0$ ka points to a transition to drier late Holocene and reduction in rainfall. The dry phase could be linked to $4.2 \mathrm{ka}$ event known as a very dry Holocene climatic event (De Menocal 2001). There are many supporting evidence of drought conditions that began before $4.5 \mathrm{ka}$ and has only moderately recovered (Rashid et al. 2013). In Croatia, dry conditions at $4.0 \mathrm{ka}$ have been observed in the reduced input of fresh water in the Mirna river valley in Istria (Kaniewski et al. 2016). Phase of intense drought $\sim 4.2 \mathrm{ka}$ is recorded across North Africa (Gasse \& Van Campo 1994), Eastern Mediterranean and the Red Sea (Bar-Matthews et al. 1997) Italy (Buca della Renello cave) (Drysdale et al. 2006). Furthermore, speleothem record from Belgium for the $5 \mathrm{a}-3 \mathrm{ka}$ time period suggests a progressive drying with high dry-wet variability and very dry peaks at $5.2 \mathrm{ka}$ and $4.5 \mathrm{ka}$ (Verheyden et al. 2014). 


\section{CONCLUSIONS}

Despite the lower dating resolution for Holocene period, preliminary results of this study provide valuable new information about the eastern Adriatic paleoenvironmental conditions during the Early and Middle Holocene and are comparable to similar results obtained from other parts of Europe and the world. The average value of d-excess of analysed dripwater of $9.3 \%$ indicates that the atmospheric conditions over the Atlantic Ocean has greater influence on the isotopic value of the precipitation from Adriatic than Mediterranean atmospheric conditions, which coincides with other similar researches conducted in Croatia.

The Holocene is marked by numerous $\delta^{18} \mathrm{O}_{c}$ and $\delta^{13} \mathrm{Cc}$ fluctuations reflecting many and sudden changes in the environment superimposed on a general increasing trend of $\delta^{18} \mathrm{O}$ values from early to mid-Holocene. Generally, low $\delta^{18} \mathrm{O}_{c}$ and $\delta^{13} \mathrm{C}_{c}$ of speleothems MSM-1 and VSM-1 correspond to wetter conditions, while high $\delta^{18} \mathrm{O}_{c}$ and $\delta^{13} \mathrm{C}_{\mathrm{c}}$ values correspond to relatively dry conditions. Mid-Holocene climate is characterized by fluctuations between relatively wet and relatively dry conditions. $\mathrm{Hu}$ - mid conditions are particularly pronounced by low $\delta^{18} \mathrm{O}_{c}$ and $\delta^{13} \mathrm{C}_{c}$ values of speleothem MSM-1 between $7.3 \mathrm{ka}$ and $6 \mathrm{ka}$ and can be related to the deposition of Sapropel (S1). Transition to today's Mediterranean climate (Cs) in the eastern Adriatic which occurred between $6 \mathrm{ka}$ and 5 $\mathrm{ka}$ is recorded in MSM-1 between $6.5 \mathrm{ka}$ and $5.5 \mathrm{ka}$ and was occasionally interrupted by wet intervals. Also, there is a general trend towards drier conditions especially after $5 \mathrm{ka}$. The main dry events are recorded at $6.8 \mathrm{ka}$, $\sim 6 \mathrm{ka}, 4.8 \mathrm{ka}$ and $4.3 \mathrm{ka}$, and the wettest events are at $7.2 \mathrm{ka}, 6.6 \mathrm{ka}$ and $5.5 \mathrm{ka}$.

Reconstruction of past vegetation and climate in the Mljet Island area allowed us to induce a general background for understanding local settings in the context of regional change driven by the environmental and climate changes across the Adriatic region. MSM-1 and VSM-1 speleothem records have revealed new ideas and questions about the regional and large scale past climates fluctuation in the research area, emphasizing the need for a more extensive network of paleoclimate records from Croatia to better understand Holocene climate.

\section{ACKNOWLEDGEMENT}

This research was supported by UKF Grant Agreement No. 71/10 and Geological Survey of Israel where all laboratory work and analyses were performed. The authors wish to thank to P. Kovač Konrad, N. Buzjak, V. Jalžić, D. Henc, K. Motočić, T. Guščić, V. Šarunić and Nature Park
Mljet for assistance during the field work. For the datasets and useful suggestions we are grateful to R. N. Drysdale, D. Genty and F. McDermott. We would also like to thank the independent reviewers whose comments and suggestions improved the quality of this paper.

\section{REFERENCES}

Adams, J., 1997: Europe during the last 150,000 years.In: Adams, J. \& H. Faure (eds.) Review and Atlas of Palaeovegetation. Preliminary Land Ecosystem Maps of the World since the Last Glacial Maximum. Environmental Sciences Division (Oak Ridge National Laboratory) [Online] Available from: http:// www.esd.ornl.gov/projects/qen/nercEUROPE.html [Accessed 31 $1^{\text {st }}$ August 2016].

Adams, J. \& H. Faure, 1997: Preliminary Vegetation Maps of the World since the Last Glacial Maximum: An Aid to Archaeological Understanding.- Journal of Archaeological Science, 24, 7, 623-647. DOI: https://doi.org/10.1006/jasc.1996.0146.
Adams, J., Maslin, M. \& E. Thomas, 1999: Sudden climate transitions during the Quaternary. - Progress in Physical Geography, 23, 1, 1-36. DOI: https:// doi.org/10.1177/030913339902300101.

Artegiani, A., Paschini, E., Russo, A., Bregant, D., Raicich, F. \& N. Pinardi, 1997: The Adriatic Sea General Circulation. Part I: Air-Sea Interactions and Water Mass Structure.- Journal of Physical Oceanography, American Meteorological Society, 27, 8, 1492-1514. DOI: https://doi.org/10.1175/1520-04 85(1997)027<1492:TASGCP>2.0.CO;2. 
Ayalon, A., Bar-Matthews, M. \& E. Sass, 1998: Rainfallrecharge relationships within a karstic terrain in the Eastern Mediterranean semi-arid region, Israel: $\delta^{18} \mathrm{O}$ and $\delta \mathrm{D}$ characteristics.- Journal of Hydrology, 207, 18-31. DOI: https://doi.org/10.1016/S00221694(98)00119-X.

Ayalon, A., Bar-Matthews, M. \& B. Schilman, 2004: Rainfall isotope characteristics at various sites in Israel and the relationships with unsaturated zone water. Israel Geological Survey Report GSI/16/04, pp.104, Jerusalem.

Bakrač, K., Ilijanić, N., Miko, S. \& O. Hasan, 2015: Evidence of sapropel S1 formation from Holocene lacustrine sequences in Northern Dalmatia (Vrana Lake).- In: Horvat M. \& L. Wacha (eds.) Abstracts book, $5^{\text {th }}$ Croatian Geological Congress, $23^{\text {th }}-25^{\text {th }}$ September 2015, Osijek, pp. 19-20, Osijek.

Bard, E., Delaygue, G., Rostek, F., Antonioli, F., Silenzi, S. \& D.P. Schrag, 2002: Hydrological conditions over the western Mediterranean basin during the deposition of the cold Sapropel 6 (ca. 175 kyr BP).- Earth and Planetary Science Letters, 202, 2, 481-494. DOI: https://doi.org/10.1016/S0012-821X(02)00788-4.

Barešić, J., Horvatinčić, N., Krajcar Bronić, I., Obelić, B. \& P. Vreča, 2011: Stable isotope composition of daily and monthly precipitation in $\mathrm{Za}$ greb.- Isotopes in Environmental and Health Studies, 42, 3, 239-249. DOI: http://dx.doi. org/10.1080/10256010600840226.

Bar-Matthews, M. \& A. Ayalon, 2011: Mid-Holocene climate variations revealed by high-resolution speleothem records from Soreq Cave, Israel and their correlation with cultural changes.- The Holocene, 21, 1, 163-171. DOI: https://doi. org/10.1177/0959683610384165.

Bar-Matthews, M., Ayalon, A., Matthews, A., Sass, E. \& L. Halicz, 1996: Carbon and oxygen isotope study of the active water-carbonate system in a karstic Mediterranean cave: implications for paleoclimate research in semi-arid regions.- Geochimica et Cosmochimica Acta, 60, 337-347. DOI: https://doi. org/10.1016/0016-7037(95)00395-9.

Bar-Matthews, M., Ayalon, A. \& A. Kaufman, 1997: Late Quaternary Paleoclimate in the Eastern Mediterranean Region from stable Isotope Analysis of Speleothems at Soreq Cave, Israel.- Quaternary Research, 47, 2, 155-168. DOI: https://doi.org/10.1006/ qres.1997.1883.
Bar-Matthews, M., Ayalon, A., Kaufman, A. \& G.J. Wasserburg, 1999: The Eastern Mediterranean paleoclimate as a reflection of regional events: Soreq Cave, Israel.- Earth and Planetary Science Letters, 166, 85-95. DOI; https://doi.org/10.1016/S0012-821$\mathrm{X}(98) 00275-1$.

Bar-Matthews, M., Ayalon, A. \& A. Kaufman, 2000: Timing and hydrological conditions of Sapropel events in the Eastern Mediterranean, as evident from speleothems, Soreq Cave, Israel.- Chemical Geology, 169, 145-156. DOI: https://doi.org/10.1016/S00092541(99)00232-6.

Bar-Matthews, M., Ayalon, A., Gilmour, M., Matthews, A. \& C.J. Hawkesworth, 2003: Sea-land oxygen isotopic relationship from planktonic foraminifera and speleothems in the Eastern Mediterranean region and their implication for paleorainfall during interglacial intervals.- Geochimica et Cosmochimica Acta, 67, 3181-3199. DOI: https://doi.org/10.1016/ S0016-7037(02)01031-1.

Belli, R., Frisia, S., Borsato, A., Drysdale, R., Hellstrom, J., Zhao J.-x. \& C. Spötl, 2013: Regional climate variability and ecosystem responses to the last deglaciation in the northern hemisphere from stable isotope data and calcite fabrics in two northern Adriatic stalagmites.- Quaternary Science Reviews, 72, 146-158. DOI: https://doi.org/10.1016/j. quascirev.2013.04.014.

Bognar, A. \& Z. Curić, 1995: Geomorfološke značajke Mljeta.- In: Durbešić, P., \& A. Benović, (eds.) Ekološke monografije 6, Mljet: Zbornik radova sa simpozija prirodne značajke i društvena valorizacija otoka $\mathrm{Ml}$ jeta, $4^{\text {th }}-10^{\text {th }}$ September 1995 , Pomena, Hrvatsko ekološko društvo etc., pp. 73-84., Pomena.

Bognar, A., Faivre, S., Buzjak, N., Pahernik, M. \& N. Bočić, 2012: Recent landform evolution in the Dinaric and Pannonian Region of Croatia. - In: Lóczy, D., Stankoviansky, M., \& A. Kotarba (eds.) Recent Landform Evolution, Springer, pp. 313-344, Heidelberg.

Bond, G., Kromer, B., Beer, J., Muscheler, R., Evans, M. N., Showers, W., Hoffmann, S., Lotti-Bond, R., Hajdas, I. \& G. Bonani, 2001: Persistent solar influence on North Atlantic climate during the Holocene.- Science, 294, 2130-2136. DOI: https:/doi. org/10.1126/science.1065680.

Brayshaw, D.J., Rambeau, C.M.C., \& J.C. Smith, 2011: Changes in Mediterranean climate during the Holocene: Insights from global and regional climate modelling.- The Holocene, 21, 1, 5-31. DOI: https:// doi.org/10.1177/0959683610377528. 
Celle-Jeanton, H., Travi, Y. \& B. Blavoux, 2001: Isotopic typology of the precipitation in the Western Mediterranean region at three different time scales.Geophysical Research Letters, 28, 1215-1218. DOI: https://doi.org/10.1029/2000GL012407.

Church, J.A., White, N.J., Coleman, R., Lambeck, K. \& J.X. Mitrovica, 2004: Estimates of the regional distribution of sea level rise over the 1950-2000 period.- Journal of Climate, 17, 13, 2609-2625. DOI: https://doi.org/10.1175/1520-0442(2004)017$<2609$ :EOTRDO>2.0.CO;2.

CMHS, 2010: Croatian Meteorological and Hydrological Srevice, Average monthly and annual air temperature $\left({ }^{\circ} \mathrm{C}\right)$ and mean monthly and annual precipitation (mm) for the stations: Krk, Rijeka Airport, Omišalj, Cres, Mali Lošinj, Božava, Knin, Bol, Sumartin, Vis and Govedari, for the 1981-2008 period, KLASA:. 920-03/10-01/537, URBROJ: 554-0302/15-10-02, 30. 06. 2010.

Combourieu-Nebout, N., Peyron, O., Bout-Roumazeilles, V., Goring, S., Dormoy, I., Joannin, S., Sadori, L., Siani, G. \& M. Magny, 2013: Holocene vegetation and climate changes in central Mediterranean inferred from a high-resolution marine pollen record (Adriatic Sea).- Climate of Past Discussions, 9, 1969-2014. DOI: https://doi.org/10.5194/ cp-9-2023-2013.

Cushman-Roisin, B., Gačić, M. \& P.-M. Poulain, 2001: Physical oceanography of the Adriatic Sea.- Kluwer Academic Publishers, pp. 304, Dordrecht.

Dahl, S.O., Nesje, A., Lie, O., Fjordheim, K. \& J.A Matthews, 2002: Timing, equilibrium-line altitudes and climatic implications of two early-Holocene glacier readvances during the Erdalen Event at Jostedalsbreen, western Norway.- The Holocene, 12, 1, 17-25. DOI: https://doi.org/10.1191/0959683602hl516rp.

Dansgaard, W., 1964: Stable isotopes in precipitation.- Tellus, 16, 436-468. DOI: https://dx.doi. org/10.3402/tellusa.v16i4.8993.

Davis, B.A.S., Brewer, S., Stevenson, A.C., Guiot, J. \& Data Contributors, 2003: The temperature of Europe during the Holocene reconstructed from pollen data.Quaternary Science Reviews, 22, 1701-1716. DOI: https://doi.org/10.1016/S0277-3791(03)00173-2.

De Menocal, P.B., 2001: Cultural Responses to Climate Change During the Late Holocene.- Science, 292, 5517, 667-673.

Dorale, J.A. \& Z.H. Liu, 2009: Limitations of Hendy test criteria in judging the paleoclimatic suitability of speleothems and the need for replication.- Journal of Cave and Karst Studies, 71, 73-80.
Dreybrodt, W. \& D. Scholz, 2011: Climatic dependence of stable carbon and oxygenisotope signals recorded in speleothems: from soil water to speleothem calcite.Geochimica et Cosmochimica Acta, 75, 734-752. DOI: https://doi.org/10.1016/j.gca.2010.11.002.

Drysdale, R.N., Zanchetta, G., Hellstrom, J.C., Fallick, A.E., Zhao, J-x., Isola, I. \& G. Bruschi, 2004: Palaeoclimatic implications of the growth history and stable isotope $\left(\delta^{18} \mathrm{O}\right.$ and $\left.\delta^{13} \mathrm{C}\right)$ geochemistry of a Middle to Late Pleistocene stalagmite from centralwestern Italy.- Earth and Planetary Science Letters, 227, 215-229. DOI: https://doi.org/10.1016/j. epsl.2004.09.010.

Drysdale, R.N., Zanchetta, G., Hellstrom, J.C., Fallick, A.E. \& J-x. Zhao, 2005: Stalagmite evidence for the onset of the Last Interglacial in southern Europe at $129 \pm$ 1 ka.- Geophysical Research Letters, 32, 24, L24708. DOI: https://doi.org/10.1029/2005GL02465.

Drysdale, R.N., Zanchetta, G., Hellstrom, J.C., Maas, R., Fallick, A.E., Pickett, M., Cartwright, I. \& L. Piccini, 2006: Late Holocene drought responsible for the collapse of Old World civilizations is recorded in an Italian cave flowstone.- Geology, 34, 2, 101-104. DOI: https://doi.org/10.1130/G22103.1.

Drysdale, R.N., Hellstrom, J.C., Zanchetta, G., Fallick, A.E., Sánchez Goñi, M.F., Couchoud, I., McDonald, J., Maas, R., Lohmann, G. \& I. Isola, 2009: Evidence for Obliquity Forcing of Glacial Termination II.- Science, 325, 1527-1531. DOI: https://doi. org/10.1126/science.1170371.

Duplančić Leder, T., Ujević, T. \& M. Čala, 2004: Duljine obalne crte i površine otoka na hrvatskom dijelu Jadranskog mora određene $s$ topografskih karata mjerila 1:25 000.- Geoadria, 9, 1, 5-32.

Epstein, S. \& T.K. Mayda, 1953: Variations of the ${ }^{18} \mathrm{O} /{ }^{16} \mathrm{O}$ ratio in natural waters.- Geochimica et Cosmochimica Acta, 4, 213-224. DOI: https://doi. org/10.1016/0016-7037(53)90051-9.

Fairbridge, R. W. (ed.), 1968: The encyclopedia of geomorphology. Reinhold Book Corp, pp. 1295, New York.

Fairchild, I.J., Smith, C.L., Baker, A., Fuller, L., Spötl, C., Mattey, D., McDermott, F. \& E.I.M.F., 2006: Modification and preservation of environmental signals in speleothems.- Earth Science Reviews, 75, 105-153. DOI: https://doi.org/10.1016/j. earscirev.2005.08.003.

Fairchild, I.J., Tuckwell, G.W., Baker, A. \& A.F. Tooth, 2006: Modeling of dripwater hydrology and hydrogeochemistry in a weakly karstified aquifer (Bath, UK): implications for climate change studies.- Journal of Hydrology, 321, 213-231. DOI: https://doi. org/10.1016/j.jhydrol.2005.08.002. 
Filipčić, A., 2000: Razgraničenje Koppenovih klimatskih tipova Cf i Cs u Hrvatskoj.- Acta Geographica Croatica, 35, 7-18.

Frisia, S., Borsato, A., Mangini, A., Spötl, C., Madonia, G. \& U. Sauro, 2006: Holocene climate variability in Sicily from a discontinuous stalagmite record and the Mesolithic to Neolithic transition.- Quaternary Research, 66, 388-400. DOI: https://doi. org/10.1016/j.yqres.2006.05.003.

Gascoyne, M., 1992: Paleoclimate determination from cave calcite deposits.- Quaternary Science Reviews, 11, 609-632. DOI: https://doi.org/10.1016/02773791(92)90074-I.

Gasse, F. \& E. Van Campo, 1994: Abrupt post-glacial climate events in West Asia and North Africa monsoon domains.- Earth and Planetary Science Letters, 126, 4, 435-456. DOI: https://doi.org/10.1016/0012821X(94)90123-6.

Gat, J.R. \& I. Carmi, 1987: Effect of climate changes on the precipitation patterns and isotopic composition of water in a climate transition zone: case of the Eastern Mediterranean Sea area. In: Solomon, S. I et al. (eds.) The Influence of Climate Change and Climatic Variability on the Hydrologic Regime and Water Resources., IAHS Publication 168, pp. 513-523, Vancouver.

Genty, D. \& M. Massault, 1997: Bomb ${ }^{14} \mathrm{C}$ recorded in laminated speleothems: calculation of dead carbon proportion.- Radiocarbon, 39, 33-48. DOI: https:// doi.org/10.1017/S0033822200040881

Genty, D. \& M. Massault, 1999: Carbon transfer dynamics from bomb- ${ }^{14} \mathrm{C}$ and $\delta^{13} \mathrm{C}$ time series of a laminated stalagmite from SW France - Modeling and comparison with other stalagmite records.- Geochimca et Cosmochimica Acta, 63, 1537-1548. DOI: https://doi.org/10.1016/S0016-7037(99)00122-2.

Genty, D., Blamart, D., Ghaleb, B., Plagnes, V., Causs, Ch., Bakalowicz, M., Zouari, K., Chkir, N., Hellstrom, J.C., Wainer, K. \& F. Bourges, 2006: Timing and dynamics of the last deglaciation from European and North African $\mathrm{d}^{13} \mathrm{C}$ stalagmite profiles-comparison with Chinese and South Hemisphere stalagmites.Quaternary Science Reviews, 25, 2118-2142. DOI: https://doi.org/10.1016/j.quascirev.2006.01.030.

Giraudi, C., Magny, M., Zanchetta, G. \& R.N. Drysdale, 2011. The Holocene climatic evolution of Mediterranean Italy: A review of the continental geological data.- The Holocene, 21, 1, 105-115. DOI: https:// doi.org/10.1177/0959683610377529.
Gopher, A., Ayalon, A., Bar-Matthews, M., Barkai, R., Frumkin, A., Karkanas, P. \& R. Shahack-Gross, 2010: The chronology of the late Lower Paleolithic in the Levant based on U-Th ages of speleothems from Qesem Cave, Israel.- Quaternary Geochronology, 5, 644-656. DOI: https://doi.org/10.1016/j. quageo.2010.03.003.

Göktürk, O.M., Fleitmann, D., Badertscher, S., Cheng, H., Edwards, R.L., Leuenberger, M., Fankhauser, A., Tüysüz, O. \& J. Kramers, 2011: Climate on the southern Black Sea coast during the Holocene: implications from the Sofular Cave record.- Quaternary Science Review, 30, 2433-2445. DOI: https:// doi.org/10.1016/j.quascirev.2011.05.007.

Grisogono, B. \& D. Belušić, 2009: A review of recent advances in understanding the meso- and microscale properties of the severe Bora wind.- Tellus A, 61, 1-16. DOI: https://doi.org/10.1111/j.1600-0870 .2008.00369.x.

Harrison, S.P., Prentice, I.C. \& J. Guiot, 1993: Climatic controls on Holocene lake-level changes in Europe.- Climate Dynamics, 8, 189-200. DOI: https:// doi.org/10.1007/BF00207965.

Horvatinčić, N., Srdoč, D., Šilar, J. \& H. Tvrdikova, 1989: Comparison of the ${ }^{14} \mathrm{C}$ activity of groundwater and recent tufa from karst areas in Yugoslavia and Czechoslovakia.- Radiocarbon, 31, 884-892. DOI: https://doi.org/10.1017/S0033822200012509.

Horvatinčić, N., Čalić, R. \& M.A. Geyh, 2000: Interglacial Growth of Tufa in Croatia.- Quaternary Research, 53, 185-195. DOI: https://doi.org/10.1006/ qres.1999,2094.

Horvatinčić, N., Krajcar Bronić, I. \& B. Obelić, 2003: Differences in the ${ }^{14} \mathrm{C}$ age, $\delta^{13} \mathrm{C}$ i $\delta^{18} \mathrm{O}$ of the Holocene tufa and speleothems in the Dinaric karst.- Palaeogeography, Palaeoclimatology, Palaeoecology, 193, 139-157. DOI: https://doi.org/10.1016/S00310182(03)00224-4.

Horvatinčić, N., Krajcar Bronić, I., Barešić, J., Obelić, B. \& S. Vidič, 2005: Tritium and stable isotope distribution in the atmosphere at the coastal region of Croatia, In: Isotopic composition of precipitation in the Mediterranean Basin in relation to air circulation patterns and climate. Final report of a coordinated research project 2000-2004, International Atomic Energy Agency, pp. 37-50, Vienna.

Horvatinčić, N., Barešić, J., Babinka, S., Obelić, B., Krajcar Bronić, I., Vreča, P. \& A. Suckow, 2008: Towards a deeper understanding how carbonate isotopes $\left({ }^{14} \mathrm{C}\right.$, ${ }^{13} \mathrm{C},{ }^{18} \mathrm{O}$ ) reflect environmental changes: A study with recent $210 \mathrm{~Pb}$-dated sediments of the Plitvice Lakes, Croatia.- Radiocarbon, 50, 2, 233-253. DOI: https://doi.org/10.1017/S0033822200033543. 
Hunjak, T., Lutz, H.O. \& Z. Roller-Lutz, 2013: Stable isotope composition of the meteoric precipitation in Croatia.- Isotopes in environmental and health studies, 49, 3, 336-345. DOI: https://doi.org/10.10 80/10256016.2013.816697.

Jahns, S. \& C. van den Bogaard, 1998: New palynological and tephrostratigraphical investigations of two salt lagoons on the island of Mljet, south Dalmatia, Croatia.- Vegetation History and Archaeobotany, 7, 219-234. DOI: https://doi.org/10.1007/ BF01146195.

Jalut, G., Amat, A.E., Bonnet, L., Gauquelin, T. \& M. Fontugne, 2000: Holocene climatic changes in the Western Mediterranean, from south-east France to south-east Spain.- Palaeogeography, Palaeoclimatology, Palaeoecology, 160, 255-290. DOI: ttps:// doi.org/10.1016/S0031-0182(00)00075-h4.

Jalžić, B., 2007: Medvjeđa špilja na otoku Lošinju.- Speleolog, Jalžić, B., Bilandžija, H., Bedek, J., Dražina, T., Lukić, M., Miculinić, K., Pavlek, M., Perkić, D. \& V. Štamol, 2007: Istraživanja podzemlja otoka Mljeta Izvješće, Hrvatsko biospeleološko društvo, pp. 160, Zagreb.

Jelaska, V., 2002: Carbonate platforms of the External Dinarides. In: Vlahović, I. \& J. Tišljar (eds.) Evolution of Depositional Environments from the Palaeozoic to the Quaternary in the Karst Dinarides and Pannonian Basin. Field Trip Guidebook, 22 ${ }^{\text {nd }}$ IAS Meeting of Sedimentology, 17 $7^{\text {th }}-19^{\text {th }}$ September 2003, Opatija, Institute of Geology, 67-71, Opatija.

Kaiser, T. \& S. Forenbaher, 2002: Krajicina spilja i brončano doba otoka Visa.- Opvscvla Archaeologica, 26, 99-110.

Kallel, N., Paterne, M., Labeyrie, L., Duplessy, J.-C. \& M. Arnold, 1997: Temperature and salinity records of the Thyrrhenian Sea during the last 18,000 years.Palaeogeography, Palaeoclimatology, Palaeoecology, 135, 97-108. DOI: https://doi.org/10.1016/ S0031-0182(97)00021-7.

Kaniewski, D., Marriner, N., Morhange, Ch., Faivre, S., Otto, T. \& E. Van Campo, 2016: Solar pacing of storm surges, coastal flooding and agricultural losses in the Central Mediterranean.- Scientific Reports, 6, 1-12. DOI: https://doi.org/10.1038/srep25197.

Kaufman, A., Wasserburg, G.J., Porcelli, D., Bar-Matthews, M., Ayalon, A. \& L. Halicz, 1998: U-Th isotope systematics from the Soreq Cave Israel and climatic correlations.- Earth Planetary Science Letters, 156, 141-155. DOI: https://doi.org/10.1016/ S0012-821X(98)00002-.
Krajcar Bronić, I., Vreča, P., Horvatinčić, N., Barešić, J. \& B. Obelić, 2006: Atmospheric ${ }^{2} \mathrm{H},{ }^{3} \mathrm{H},{ }^{18} \mathrm{O},{ }^{13} \mathrm{C}$ and ${ }^{14} \mathrm{C}$ isotopes in Croatia and Slovenia.- Arhiv za Higijenu Rada i Toksikologiju, 57, 23-29.

Lambeck, K. \& J. Chappell, 2001: Sea level change through the Last Glacial Cycle.- Science, 292, 679-686. DOI: http://doi.org/10.1126/science.1059549.

Lionello, P., Malanotte-Rizzoli, P., Boscolo, R., Alpert, P., Artale, V., Li, L., Luterbacher, J., May, W., Trigo, R., Tsimplis, M., Ulbrich, U. \& E. Xoplaki, 2006: The Mediterranean climate: An overview of the main characteristics and issues.- Developments in Earth and Environmental Sciences, 4, 1-26. DOI: https:// doi.org/10.1016/S1571-9197(06)80003-0.

Lončar, N., 2012: Isotopic composition of the speleothems from the eastern Adriatic islands caves as an indicator of palaeoenvironmental changes.- $\mathrm{PhD}$ thesis. University of Zagreb, pp. 263.

Lowe, J.J. \& M.J.C. Walker, 1998: Reconstructing Quaternary Environments, $2^{\text {nd }}$ ed.- Routledge, pp. 446, London.

Luetscher, M., Hoffmann, D.L., Frisia, C. \& C. Spötl, 2011: Holocene glacier history from alpine speleothems, Milchbach Cave, Switzerland.- Earth and Planetary Science Letters, 302, 95-106. DOI: https://doi.org/10.1016/j.epsl.2010.11.042.

Malez, M. \& S. Božičević, 1965: The Medvjeđa pećina (Bear Cave) on Lošinj Island, A rare case of submerged cave.- In: Stelcl, O. (ed.) International Speleological Conference, Brno, Problems of Speleological Research, 29 ${ }^{\text {th }}$ June-4 $4^{\text {th }}$ July 1964, Prague, pp. 211-216, Prague.

Manca, M., Nocentini, A.M., Belis, C.A., Comoli, P. \& L. Corbella, 1996: Invertebrate fossil remains as indicators of late Quaternary environmental changes in Latium Crater lakes (L. Albano and L. Nemi).Memorie dell'Istituto Italiano di Idrobiologia, 55, 149-176.

Magny, M., Vannière, B., Zanchetta, G. Fouache, E., Touchais, G., Petrika, L., Coussot, C., Walter-Simonnet A.-W. \& F. Arnaud, 2009: Possible complexity of the climatic event around 4300-3800 cal. BP in the central and western Mediterranean.The Holocene 19, 6, 823-833. DOI: https://doi. org/10.1177/0959683609337360.

Marchal, O., Cacho, I., Stocker, T.F., Grimalt, J.O., Calvo, E. \& B. Martrat, 2002: Apparent long-term cooling of the sea surface in the northeast Atlantic and Mediterranean during the Holocene.- Quaternary Science Reviews, 21, 455-483. DOI: https:/doi. org/10.1016/S0277-3791(01)00105-6. 
Mayewski, P.A., Meeker, L.D., Twickler, M.S., Whitlow, S., Yang, Q., Lyons, W.B. \& M. Prentice, 1997: Major features and forcing of high latitude northern hemisphere atmospheric circulation using 110000-year long glaciochemical series.- Journal of Geophysics Research 102, 26, 345-366. DOI: https://doi. org/10.1029/96JC03365.

McDermott, F., Frisia, S., Huang, Y., Longinelli, A., Spiro, B., Heaton, T.H.E., Hawkesworth, C.J., Borsato, A., Keppens, E., Fairchild, I.J., van der Borg, K., Verheyden, S. \& E. Selmo, 1999: Holocene climate variability in Europe: evidence from $\delta^{18} \mathrm{O}$, textural and extension rate variations in three speleothems.Quaternary Science Reviews, 18, 1021-1038. DOI: https://doi.org/10.1016/S0277-3791(98)00107-3.

Moreno, A., Stoll, H., Jiménez-Sánchez, M., Cacho, I., Valero-Garcés, B., Ito, E. \& R.L. Edwards, 2010: A speleothem record of glacial (25-11.6 kyr BP) rapid climatic changes from northern Iberian Peninsula.Global and Planetary Change, 71, 218-231. DOI: https://doi.org/10.1016/j.gloplacha.2009.10.002

Nelson, S.T., 2000: A simple, practical methodology for routine VSMOW/SLAP normalization of water samples analyzed by continuous flow methods.Rapid Communications in Mass Spectrometry, 14, 1044-1046. DOI: https://doi.org/10.1002/10970231(20000630)14:12<1044::AID-RCM987>3.0. $\mathrm{CO} ; 2-3$.

Peel, M.C., Finlayson, B.L. \& T.A. McMahon, 2007: Updated world map of the Köppen-Geiger climate classification.- Hydrology and Earth System Sciences Discussions, 4, 2, 439-473. DOI: https://doi. org/10.5194/hess-11-1633-2007.

Penzar, B., Penzar, I. \& M. Orlić, 2001: Vrijeme i klima hrvatskog Jadrana. Biblioteka Geographica Croatica, Knjiga 16, Dr. Feletar, pp. 258, Zagreb.

Peyron, O., Goring, S., Dormoy, I., Kotthoff, U., Pross, J., de Breaulieu, J.-L., Drescher-Schneider, R., Vanière, B. \& M. Magny, 2011: Holocene seasonality changes in the central Mediterranean region reconstructed from the polen sequences of Lake Accesa (Italy) and Tenaghi Philippon (Greece). The Holocene, 21, 1, 131-146. DOI: https://doi. org/10.1177/0959683610384162.

Prelogović, E., Aljinović, B. \&. S Bahun, 1995: New data on structural relationships in the Nothern Dalmatian Dinaride Area.- Geologia Croatica, 48, 2, 167-176.
Rashid, H., Otieno, F.O., Best, K.M. \& C.K. Shum, 2013: Analysis of Paleoclimate Records for Understanding the Tropical Hydrologic Cycle in Abrupt Climate Change. In: Pielke, R.A. \& F. Hossain (eds.) Climate Vulnerability: Understanding and Addressing Threats to Essential Resources. Elsevier, Academic Press, pp.127-139, Amsterdam.

Richards, D.A. \& J.A. Dorale, 2003: Uranium-series Chronology and Environmental Applications of Speleothems. In: Bourdon, B., Henderson, G, M., Lundstrom, C. C. \& S. P Turner (eds.) Uranium Series Geochemistry, Reviews in Mineralogy and Geochemistry 52, Geochemical Society, Mineralogical Society of America, pp. 407-460, Washington DC.

Regattieri, E., Zanchetta, G., Drysdale, R.N., Isola, I., Hellstrom, J.C. \& L. Dallai, 2014: Lateglacial to Holocene trace element record ( $\mathrm{Ba}, \mathrm{Mg}, \mathrm{Sr}$ ) from Corchia Cave (Apuan Alps, central Italy): $\mathrm{Pa}-$ leoenvironmental implications.- Journal of Quaternary Science, 29, 4, 381-392. DOI: https:/doi. org/10.1002/jqs.2712.

Roberts, N., Brayshaw, D., Kuzucuoglu, C., Perez, R. \& L. Sadori, 2011: The mid-Holocene climatic transition in the Mediterranean: Causes and consequences.- The Holocene, 21, 1, 3-13. DOI: https://doi. org/10.1177/0959683610388058.

Roller-Lutz, Z., Mance, D., Hunjak, T. \& H.O. Lutz, 2013: On the isotopic altitude effect of precipitation in the Northern Adriatic (Croatia). In: International Symposium on Isotopes in Hydrology, Marine Ecosystems, and Climate Change Studies, Monaco, 27 ${ }^{\text {th }}$ March$1^{\text {st }}$ April 2011, Vienna, IAEA-CN-186/12, IAEA, pp. 99-105, Vienna.

Rudzka, D., McDermott, F. \& M. Surić, 2012: A late Holocene climate record in stalagmites from Modrič Cave (Croatia).- Journal of Quaternary Science, 27, 6, 585-596. DOI: https://doi.org/10.1002/jqs.2550

Sanchez Goni, M.F., Eynaud, F., Turon, J.-L. \& N.J. Shackleton, 1999: High resolution palynological record off the Iberian margin: direct land-sea correlation for the last interglacial complex.- Earth and Planetary Science Letters, 171, 123-137. DOI: https:// doi.org/10.1016/S0012-821X(99)00141-7.

Schmidt, R., Müller, J., Drescher-Schneider, R., Krisai, R., Szeroczyńska, K. \& A. Barić, 2000: Changes in lake level and trophy at Lake Vrana, a large karstic lake on the Island of Cres (Croatia), with respect to palaeoclimate and anthropogenic impacts during the last approx. 16,000 years.- Journal of Limnology, 59, 2, 113-130. DOI: https://doi.org/10.4081/ jlimnol.2000.113. 
Spötl, C., Nicolussi, K., Patzelt, G., Boch, R. \& Daphne team, 2010: Humid climate during deposition of sapropel 1 in the Mediterranean Sea: Assessing the influence on the Alps.- Global and Planetary Change, 71, 242-248. DOI: https://doi. org/10.1016/j.gloplacha.2009.10.003.

Surić, M. \& M. Juračić, 2010: Late Pleistocene - Holocene environmental changes - records from submerged speleothems along the Eastern Adriatic coast (Croatia).- Geologia Croatica, 63, 2, 155-169.

Surić, M., Roller-Lutz, Z., Mandić, M., Krajcar Bronić, I. \& M. Juračić, 2010: Modern C, O, and H isotope composition of speleothem and dripwater from Modrič Cave, eastern Adriatic coast (Croatia).International Journal of Speleology, 39, 2, 91-97. DOI: http://doi.org/10.5038/1827-806X.39.2.4.

Surić, M., Korbar, T. \& M. Juračić, 2014. Tectonic constraints on the late Pleistocene-Holocene relative sea-level change along the north-eastern Adriatic coast (Croatia).- Geomorphology, 220, 93-103. DOI: https://doi.org/10.1016/j.geomorph.2014.06.001.

Surić, M., Lončarić, R., Lončar, N., Buzjak, N., Bajo, P. \& R.N. Drysdale, 2017: Isotopic characterization of cave environments at varying altitudes on the eastern Adriatic coast (Croatia) - Implications for future speleothem based studies.- Journal of Hidrology, 545, 367-380. DOI: https://doi.org/10.1016/j. jhydrol.2016.12.051.

Šegota, T. \& A. Filipčić, 2003: Köppenova podjela klima i hrvatsko nazivlje.- Geoadria, 8, 1, 17-37.

Tzedakis, P.C., 2005: Towards an understanding of the response of southern European vegetation to orbital and suborbital climate variability.- Quaternary Science Reviews, 24, 1585-1599. DOI: https://doi. org/10.1016/j.quascirev.2004.11.012.

Vaks, A., Bar-Matthews, M., Ayalon, A., Matthews, A., Frumkin, U., Dayan, L., Halicz, A., Almogi-Labin, A. \& B. Schilman, 2006: Paleoclimate and location of the border between Maditerranean climate region and the Saharo - Arabian Desert as revealed by speleothems from the northern Negev Desert, Israel.- Earth and Planetary Science Letters, 249, 3-4, 384-399. DOI: https://doi.org/10.1016/j. epsl.2006.07.009.

Verheyden, S., Keppens, E., Quinif, Y., Cheng, H.J. \& R.L. Edwards, 2014: Late-glacial and Holocene climate reconstruction as inferred from a stalagmite - Grotte du Père Noël, Han-sur-Lesse, Belgium.Geologica Belgica, 17, 1, 83-89.
Vogel, J.C. \& J. Kronfeld, 1997: Calibration of radiocarbon dates for the late Pleistocene using U/Th dates on stalagmites.- Radiocarbon, 39, 27-32. DOI: https://doi.org/10.1017/S003382220004087.

Vreča, P., Krajcar Bronić, I., Horvatinčić, N. \& J. Barešić, 2006: Isotopic characteristics of precipitation in Slovenia and Croatia: Comparison of continental and maritime stations.- Journal of Hydrology, 330, 457-469. DOI: https://doi.org/10.1016/j. jhydrol.2006.04.005.

Weiner, K., Genty, D., Blamart, D., Daëron, M., Bar-Matthews, M., Vonhof, H., Pons-Branchu, E., Thomas, L., van Calsteren, P., Quinif, Y. \& N. Caillon, 2011: Speleothem record of the last $180 \mathrm{ka}$ in Villars cave (SW France): Investigation of a large $\delta 180$ shift between MIS6 and MIS5.- Quaternary Science Reviews, 30, 130-146. DOI: https://doi.org/10.1016/j. quascirev.2010.07.004.

Wunsam, S., Schmidt, R. \& J. Müller, 1999: Holocene lake developmentof two Dalmatian lagoons (Malo and Veliko Jezero, Isle of Mljet) in respect to changes in Adriatic sea level and climate.- Palaeogeography, $\mathrm{Pa}$ laeoclimatology, Palaeoecology, 146, 251-281. DOI: https://doi.org/10.1016/S0031-0182(98)00147-3.

Zanchetta, G., Drysdale, R.N., Hellstrom, J.C., Fallick, A.E., Isola, I., Gagan, M.K. \& M.T. Pareschi, 2007: Enhanced rainfall in the Western Mediterranean during deposition of sapropel S1: stalagmite evidence from Corchia cave (Central Italy).- Quaternary Science Reviews, 26, 279-286. DOI: https:// doi.org/10.1016/j.quascirev.2006.12.003.

Zanchetta, G., Bar-Matthews, M., Drysdale, R.N., Lionello, P., Ayalon, A., Hellstrom, J.C., Isola, I. \& E. Regattieri, 2014: Coeval dry events in the central and eastern Mediterranean basin at 5.2 and $5.6 \mathrm{ka}$ recorded in Corchia (Italy) and Soreq caves (Israel) speleothems.- Global and Planetary Change, 122, 130-139. DOI: https://doi.org/10.1016/j. gloplacha.2014.07.013.

Zanchetta, G., Regattieri, E., Isola, I., Drysdale, R.N., Bini, M., Baneschi, I. \& J.C. Hellstrom, 2016: The so-called "4.2 event" in the central Mediterranean and its climatic teleconnections.- Alpine and Mediterranean Quaternary, 29, 1, 5-17.

Zhou, J., Wang, S., Yang, G. \& H. Xiao, 2007: Younger Dryas Event and Cold Events in Early-Mid Holocene: Record from the sediment of Erhai Lake.- Advances in Climate Change Research, 1673-1719, $41-44$. 
Zonneveld, K.A.F., 1996: Palaeoclimatic reconstruction of the last deglaciation (18-8 ka B.P.) in the Adriatic Sea region; a land-sea correlation based on palynological evidence.- Palaeogeography, Palaeoclimatology, Palaeoecology, 122, 89-106. DOI: https://doi. org/10.1016/0031-0182(95)00091-7.
Wanner, H., Beer, J., Butikofer, J., Crowley, T.J., Cubasch, U., Fluckiger, J., Goosse, H., Grosjean, M., Joos, F., Kaplan, J.O., Kuttel, M., Muller, S.A., Prentice, I.C., Solomina, O., Stocker, T.F., Tarasov, P., Wagner, M. \& M. Widmann, 2008: Mid- to Late Holocene climate change: an overview.- Quaternary Science Review, 27, 1791-1828. DOI: https://doi.org/10.1016/j. quascirev.2008.06.013. 